\title{
ENFORCEABLE ARBITRATION OF COMMERCIAL DISPUTES IN THE TEXTILE INDUSTRIES*
}

TO PLAN production, guarantee profits, and remain a going concern, every business relies on the enforceability of its contracts. If demand is unpredictable and price is subject to extreme fluctuation, breach is encouraged. ${ }^{1}$ Where industry structure is complex and many contracts cover one piece of goods, chance of breach is multiplied. But court enforcement of contracts is often commercially unsatisfactory, time-consuming and expensive. ${ }^{2}$ Hence many merchants abandon valid claims rather than resort to litigation. ${ }^{3}$

*Much of the information used in this study was made available through the valuable assistance of J. Noble Braden, President of the American Arbitration Association, Irene Blunt, Secretary of the National Federation of Textiles, and H. A. Sherman, Secretary-Treasurer of the General Arbitration Council. In addition, information was gathered from three other sources: (1) A questionnaire sent to members of the textile industries who had served as arbitrators. Approximately 130 answers from merchints in cotton, rayon, silk and wool are used as source material. Respondents include yarn manufacturers, weavers, commission houses, brokers, converters, finishers, factors, importers, and garment manufacturers. The questionnaire is hereinafter referred to as the INDUSTRY QUESTIONNAIRE (2) Interviews with twenty merchants. (3) Questionnaires dispatched to lawyers familiar with textile arbitration. The lawyers' questionnaire is hereinafter cited as LAwYers' QuestionNAIRE.

1. See Eno, Price Mozement and Unstated Objections to the Defective Performance of Sales Contracts, 44 YALE L. J. 782, 800 et seq. (1935), for a general study of the relationship of price decline to breach of contract. Needless to say, in a rising market buyers are willing to accept goods even if slightly non-conforming. Llewellyn, What Prict Contract?-An Essay In Perspectiv'e, 40 Y Ale L.J. 704, 723 (1931).

2. On the inadequacies of litigation in commercial disputes see Ransom, The Organisation of the Courts for the Better Administration of Justice, 2 CokNELL L.Q. 186-201, 261-75 (1917). Ransom places his greatest emphasis on red tape, technicalities, etc., which caused justice to be uneconomic. Id. at 200 . For the commercially unsatisfactory nature of the Sales Act remedies, see Note, 35 Cor. L. Rev. 726 (1935) ; Latty, Salcs and Tiilc and the Proposcd Code, 16 LAw \& Contenrp. Pron. 3 (1951).

See Sturges, Commercial Arbitration or Court Application of Common Law Rules of Marketing? 34 YALE L.J. 480 (1925) for an analysis of time and expense in litigation and their effect on its usefulness. The study indicated that in 1924 there were 27,000 untried cases pending on the civil dockets in New York courts; additional cases piled up each year. There was little chance that a dispute arising in 1924 would be decided before 1929. Ibid.

The major items of expense, apart from court costs and counsel fees, are (1) The loss of recovery due to bankruptcies which may occur during the long litigation, Sturges, supra at 490 ; (2) The immobilization of capital during litigation. Even judgments awarding interest as well as principal were not compensatory because interest was lower than investment return on the same capital. Sturges, supra at 482.

3. Where Jury Trial Fails, 9 J. Ax. Jud. Soc'y 71-2 (1926). See Korzenik, Colltested Breach of Contract Suits, 4 ARB. J. 171 (1949) for a study of the effect of litigation on pressing of claims. Korzenik concludes that businessmen avoided litigation and hoped to make up losses later. 
Enforceable arbitration offers business men an alternative to litigation. Advocates of arbitration claim that it is a fast. inexpensive and equitable method of settling commercial disputes.* Today enough experience with commercial arbitration has accumulated to make possible the testing of these assumptions by study of arbitration in operation. The textile industriescotton, rayon, silk, and wool-offer a particularly fruitful subject for examination. Disputes are frequent." All four industries use enforceable arbitration to the virtual exclusion of litigation. "Three separate arbitration tribunals are used. ${ }^{7}$ And experience with arbitration covers a thirty-year span. ${ }^{8}$ Hence

4. Most articles which compare arbitration favorably with litigation do so on the premise that arbitration lacks the delays, costs, and injustices of court action. See Arlitration Society of America, 6 J. Axr. Jud. Soc'y 59-60 (1922): McGovern, The Laturer's Stake in Arbitration, 1 ARR. J. 128, 130 (1946). Probably the major advantage ascribad to arbitration is that businessmen may utilize it to obtain fast relief on the basis of trade custom. See Frank, Arbitrafion, 4 ARB. J. 242 (1949).

Besides advantages of speed, low cost, and use of experts, other benefits and detriments are often ascribed to arbitration: (1) Arbitration prevents litigation and even arbitration itself. Sturges, Sympositm on Commercial, Industrial, and In/crialional Arbitration, 17 N.Y.U.L.Q. Rev. 495, 496 (1940) ; Arbitration Presents a Paradox, Arbitration in Action, Jan. 1943, p. 15: (2) Arbitration breeds disputes. See Gutshal, Contract, 1 ARB. J. 116, 123 (1946) : (3) Arbitration preserves privacy. Grossman, Arbilration and the Lawyer, 17 N.Y.U.LQ. REv. 511, 513 (1940); Gotshal, The Lneyer's Place in Arbitration, 1 ARr. I. 367,371 (1946); (4) Arbitration is a friendly forum. Taeusch, Extrajudicial Settlement of Costrociersies, 83 U. of PA. L. Rev. 147, 150 (1934); Me Govern, The Lawyer's Stake in Arbitration, 1 ARB. J. 128, 133 (1946), Adrontages Ascribed to Arbitration, 9 J. AMr. Jun. Soc'y 73, 74 (1922).

5. The National Federation of Textiles (hereinafter called NFT), which handles only rayon and silk disputes, averages about 300 cases per year. In 1947 there were 301 new dockets; 1948, 424; 1949, 306; and 1950, 242. The General Arbitration Council for cotton disputes (hereinafter called G.AC) had 241 cases in 1950 but usually averages only 100 cases per year. There are no available figures on the number of woolen arbitrations in the American Arbitration Association (hereinafter called AAA). But the number of arbitrated disputes is a mere fraction of the total number of controversies in these industries. Merchants indicate that about $1 \%$ of the disputes find their way to arbitration. InDUSTRY QUESTIONNAIRE. The total number of controversies in cotton, rayon, and sills is probably upwards of 20,000 per year.

6. INDUSTRY QUESTIONAAIRE. The only branch of the textile industry which does nut use enforceable arbitration is rayon fiber manufacturing. In addition, many contracts between garment manufacturers and retailers evidently lack arbitration clauses.

7. Cotton uses the General Arbitration Council. Kayon and sill use the National Federation of Textiles. Wool uses the American Arbitration Association.

8. Enforceable arbitration in textiles originated with the Sill Assuciation in the early $1920^{\circ}$ s. At first contracts merely alluded to the sill rules which provided for arbitration, but that was not sufficient to give arbitration jurisdiction. Matter of General Sill: Importing Co. v. Gerseta Corp., 198 App. Div. 16, 189 N.Y. Supp. 391 (1st Dep't 1921). But at virtually the same time, clauses calling for arbitration were inserted in contracts and enforced. Jiatter of Wenger \& Co. v. Propper Silk Hosiery Mills, 239 N.Y. 199, 146 N.E. 203 (1924). Rayon fell in with silk arbitration in the late 1920's and cottun and wool started to use arbitration in 1930. 
the success or failure of textile arbitration should shed considerable light on its usefulness as a substitute for lawsuits in other commercial fields.

\section{The Textile Industry and Its Problems}

\section{Price, Demand, Supply, and Structure}

The price of textile goods in a contract for future delivery ${ }^{0}$ is based on estimation of demand and supply. Except for rayon, ${ }^{10}$ cost [a function of demand and supply] is unstable because a large proportion of the expense of weaving cloth derives from raw material costs which climb or dip according to supply. ${ }^{11}$ Price of cloth varies as it anticipates these crests and troughs. ${ }^{12}$

Total demand for cotton, rayon, silk and some woolen products is unpredictable. ${ }^{13}$ In part demand depends on the season of the year ${ }^{14}$ and on general

9. See Alderfer \& Michl, Economics of American Industry 375 (1950). Future marketing enables mills to produce cloth on the basis of binding orders and thus avoid waste. Bader, World Developments in the CotTon Industry 105, 125 (1925). There is also a spot market for goods to be shipped the day purchased. Prices on the spot market may differ sharply from the prices of future contract goods delivered the same day. Sec communication to the Yale LAw Journal from a broker, dated Feb. 15, 1952, on file in Yale Law Library. When the market appears volatile, buyers will purchase on the spot market or on short future delivery. The Silk Associntion 30tri Mid-Yean Reront 4 (1929) ; Daily News Record, Dec. 24, 1951, p. 5, col. 5. For trade definitions and customs relating to futures and spots, see WoRTh Street Rures 32, 33 (rev. 1947), the bible of the cotton goods industry.

10. Price of rayon fiber is fixed by the seventeen companies which produce fibers. This price normally remains constant. See Swan, The Pisin Goods Silk Industiy 4 (1937). But in the recent textile recession rayon yarn prices have been adjusted dowile wards. See Daily News Record, March 14, 1952, p. 6, col. 1.

11. The cost of raw materials constitutes approximately $50 \%$ of a weaver's expense in producing cloth. For a chart on costs, see Bates MFG. Co. Anvust Rzport 11 (1949). The relation of price of cloth produced to price of raw cotton is therefore relatively direct. See BADER, op. cit. supra note 9 at $100,103$.

12. AlderFEr \& Michl, op. cit. supra note 9, at 376. For a chart showing the relation of price climbs and dips in cloth and raw material, see BADER, op. cit. supra uote 9, at 100. For example, throughout the 1920's and early 1930's mills were buying raw cotton at steadily lower prices for each purchase. This meant that goods produced always cost more than goods that would be produced. Prices slipped accordingly. Cox, The Marketing of TEXTILES 285, 286 (1938).

Despite the stability of the price of its raw material, rayon cloth has to conform in price with its competitors. Rayon prices, therefore, also dip when cotton prices fall. Sce SwAN, op. cit. supra note 10, at 4 on price competition with silk.

13. Bader, op. cit. supra note 9, at 119 ; Cherington, The Commercial Pronlems of the Woolen and Worsted Industries 21, 22, 26 (1937). Predictability of demand varies with use to which cloth is put. Demand for cloth to be consumed industrially is relatively stable since orders are placed well in advance and are seldom breached. See Cox, op. cit. supra note 12, at 200 . Approximately $40 \%$ of cloth produced enters agricultural and industrial consumption. Internattonal Labour OfFice, THe World Texirlle INDUSTRY 18 (1937). Almost all rayon and silk cloth, however, is used for apparel. Cox, op. cit. supra note 12 , at 176 .

14. For example, demand for woolen topioats is seasonal. Daily News Record, Dec. 31,1951 , p. 2, col. 3-4. But even seasonal demand is fairly uncertain since abnormal 
prosperity, factors which offer some degree of predictability. But demand for a particular fabric hinges mainly on notoriously fickle public tastes. ${ }^{15}$ Since these fabrics are interchangeable, consumers may choose from the products of all four industries. ${ }^{16}$ Wool, for example, competes with cotton and rayon in summer suiting. Furthermore, within each industry many competing fabrics with different prints, colors, and finishes seek the same market.17 Merchants place orders for these competing fabrics on the basis of estimated demand at an expected price. But before the cloth reaches the public, time has elapsed and demand for the ordered goods may have changed. Moreover, merchants may have overestimated demand initially. As a result supply may greatly exceed demand. ${ }^{18}$ Price for the cloth reacts accordingly. ${ }^{10}$

weather may affect sales. Ihid. In cotton, rayon, and silk demand for total product as well as for particular cloths ebbs and flows seasonally. Cox, of. cit. stira note 12, at 75, 241. 291. Women's garments are especially subject to such fluctuations in demand.

15. AlDERFER \& MITCHL, op. cit. sthra note 9, at 377 (1950). Style risks are minimal in men's woolen wear but are severe in women's woolen wear. Davis, Vertical IsiteGRATTON IN THE TEXTILE INDUSTRIEs is (1938). In addition, rayon and cottun fabrics used for women's garments are subject to quick obsolescence. Cox, op. cit. supra note 12 , at $174,227-8$.

16. International Labour Office, op. cit. supra nate 13, at 20-1. Cotton and rayon compete for every market and today neither is used exclusively for any purpose. Communication to the YALE LAw Journal from a broker, dated March 12, 1952, on file in Yale Law Library. Interchangeability is marked in rayon and silk products. See Swar, op. cil. supra note 10, at 23,24 . Buyers may prefer one type of cloth over another for certain purposes, but competition in price may change preferences.

17. See Cherrngton, op. cit. supra note 13 , at $18,21,25$, and 225 for discussion of style variables in wool and worsted. Competition occurs mainly in choice between woolens and worsteds or between basic fabric structures such as tweeds and flannels.

See Cox, op. cit. supra note 12, at 70-5 for a study of the necessity of style competition in cotton and rayon. Ordinarily, staple fabrics compete with esch other. But the fiercest competition occurs in fashion innovations (color, print, cloth fatterns and cut) imposed on these fabrics. For example, in 1937 alone over 29,000 new designs were registered at the Industrial Design Registration Bureau of the NFT. Testimony of Irene Blunt, Hearings before the Subcommittee on Patents an H.R. 2560. S0th Cong., 2d Sess., 55 (1949). Only a fraction of these designs are accepted by the public each year. Cox, op. cit. supro note 12 , at $70-1$.

18. The quantity of textile goods on the market at any time is subject to quich expansion. Textile machinery has almost endless capacity. Normally, machinery runs at less than full output; production may be multiplied to meet orders without re-tooling or other changes. AzDERFER \& MIICHL, op. cit. supra note 9, at 372. Moreover, it is easy to switch from production of one type of cloth to another without replacing machinery. Ibid. Recently, for example, some mills switched their looms from unwanted fabrics such as dobbies and dress goods to cloths in greater demand-ducks and draperies. See Daily News Record, Dec. 31, 1951, p. 17, col. 3. As a result, after orders are placed, deliveries may flood the market all at once.

19. For example, in 1926 merchants guessed wrong on the popularity of a design which had been successful in chiffons and was then applied to crepe. In the econsequent dumping caused by the lack of demand, prices collapsed $50 S^{\prime}$ between January and Alay. The Silt Association 2ith IIm-Tear Refort S-9 (1926). 
The greater the style competition the larger is the number of marketing steps. ${ }^{20}$ In cotton and rayon a complex marketing structure channels production towards fashionable cloths and patterns. ${ }^{21}$ Garment manufacturers (cutters) estimate their needs in the light of style trends and place orders with converters ${ }^{22}$ (dealers in processed cloth) who in turn procure fabrics from mills (weavers) and farm out the material to finishers for processing, dyeing, and printing. In the process of translating expected demand into production, there are, therefore, a host of contracts on each piece of cloth.

\section{Breach of Contract}

The greater the number of marketing steps, the greater are the possibilities of breach. In any step delivery may be late or defects may appear, each constituting a breach of contract. Furthermore, time consumed in marketing increases the chance of price or demand fluctuation. For example, goods ordered in May for delivery in July may cost $\$ .25$ a yard, while the same goods ordered in June for October delivery may be priced at \$.20. In June, therefore, a buyer knows before delivery on his July contract that he will have difficulty disposing of goods at prices based on $\$ .25$ a yard. Accordingly, as price falls, buyers have an incentive to find defects in cloth as an excuse for rejecting goods or seeking allowances. ${ }^{23} \mathrm{~A}$ colorable excuse for

20. See Davis, Vertical Integration in the Textile Industifes (1938) for a thorough study of the effect of competition and fluctuating demand on market structure. The relationship of competition to marketing steps is well demonstrated in the sale of cotton for industrial uses. Competition in respect to styles is non-existent. As a result, industrial cotton is sold by the weaver direct to the user. AldERFER \& Mrchl, op. cit. supro note 9, at 374. Wool marketing offers another proof. Here style competition depends primarily on the weave of the goods rather than on colors or prints. Woolen mills are therefore able to undertake most processing. Cherington, op. cit. supra note 13 , at 18,22 , 25-32.

21. In addition to the firms which buy and sell each piece of goods on its journcy from the mill to the public, there are also sales agents (commission houses), brokers, factors, and finishers. On the functions of these trades see BADER, op. cit. supra note 9, at 104-5, 107, 141-7. In cotton, as in wool, weavers spin their own yarn although it is not yarn dyed. DAvis, op. cit. supra note 15 , at 12 . In rayon, however, mills purchase their yarn in colors or in the grey from fiber manufacturers. AlDERFER \& MrCHL, op. cit. supra note 9 , at $406-9$.

22. On the converting business, see testimony of Jerome Rossman, Hearings, supra note 17 , at 40 .

23. INDUSTRY QuestionNaIRE. When demand is constant and price is stable, as during World War II, buyers accept all cloth and few firms breach contracts. Hearings, supra note 17 , at 41 . The small number of disputes arbitrated during that period amply demonstrates this fact. NFT Memorandun Opposing Assembly Bill INT. No. 11272 (1949); InDustry QuestionNaIRe. In bad times returns are abnormal. Converters who ordinarily expect three to four per cent returns had up to ten per cent of their deliveries rejected during the textile recession in 1937. Business Week, Dec. 25, 1937, p. 32. In woolens, as high as $20 \%$ of the goods delivered were rejected. CuERingron, op. cit. supra 
breach is usually present because of the nature of the product 21 and a lack of technical standards for the innumerable different fabrics. ${ }^{25}$ Trade practice in classifying goods as first or second quality ${ }^{20}$ may facilitate buyers' efforts to escape. These terms are not absolute; they are based on the particular producing plant's past performance, a vague and shifting standard at best..7

\section{Litigation in Courts}

Remedies provided by the Sales Act were not wholly satisfactory to textile merchants. Since most rejections occurred in a declining market, sales of rejected goods might bring ruinously low prices. ${ }^{23}$ And the sales themselves would depress prices further. Faced with this possibility, parties held rejected cloth in the hope of market improvement, ${ }^{29}$ a course which the Sales Act

note 13 , at 38 . Even today, some garment manufacturers produce only $90 \%$ of their orders because they can expect returns of at least $10 \%$ due to drop in demand.

Although merchants rarely complain about breach by sellers during a rising market, it manifestly occurs. The typical breach is to postpone deliveries on low priced contracts in order to sell the same goods at the higher spot market prices. Communication to the YaIE LAw Journal from a broker, dated Feb. 15, 1952, on file in Yale Law Library.

24. As one cotton-rayon broker put it, "No woven goods are "perfect." Insousms: QUESTIONNAIRE. There are no woolen goods in which a bujer cannot find some imperfections. Cherrngron, op. cit. supra note 13 , at 38 .

25. Merchants agree that what one man considers up to standard another merchant might judge to be substandard. InDustry Questionsaire.

26. The difference between first and second quality is not clear. By definition second quality goods are merchantable and reasonably free from major defects; yet they are inferior to and contain more imperfections than first quality gouds. The definition says no more. A buyer may easily allege that he ordered first quality gouds and got seconds or that seconds ordered had enough defects to make them unclassifiable. First and second quality are standard phrases in the marketing of all types of textile cluth. See Worrn StreEt Rules 34-5 (rev. 1947) (cotton trade customs); Textile Distributoss InstitUte, Definitions aNd Trade Custours 3 (rayon trade customs).

27. See Worth Strfer Rules 34-5 (rev. 1947) for the cotton definition. In cottons the standard not only varies from plant to plant but also from fabric to fabric. Indusnsy QUESTIONNATRE Rayon finished goods are classified on an industry-wide standard. See Textile Distributors Institute, Definitions and Trane Custosss 3. But rayon merchants assert that the standard is just as vague as that used for cottons. IndoustnY QUESIIONNATRE.

28. Declines in price varied according to the nature of the cloth. If rejected goods were staple unfinished cloths, the seller could usually find a market at a reasonable price. But if the goods were novelties or finished to a particular buyer's specificstion, even in the absence of general price recession the seller might fail to find a purchaser. Communication to the YALE LAw Journal from a broker, dated Feb. 15, 1952, on file in Yale Law Library. See also Latty, stpra note 2, at 17.

29. Communication to the Yale Law Journal from a broker, dated Feb. 15, 1952, on file in Yale Law Library. Interviews gave further evidence of the tendency of some merchants to retain goods. 
allowed them to take when they were suing for the price. ${ }^{80}$ But if a court made its decision two to five years later, whichever party was obliged to take the goods might well suffer a heavy loss due to the obsolescence of the cloth, style, or print.

Time consumed in litigation was the cause of other problems. By the time of decision, the losing party might be bankrupt-especially if he were in a trade near the retail end where firms come and go frequently. ${ }^{31}$ Lengthy lawsuits also had an adverse effect on business relations, for few parties to court actions maintain connections with disputing customers during the period of the controversy. ${ }^{32}$

But the gravest pitfall in court enforcement of textile contracts was the inability of judge and jury to make the necessary technical decisions which a textile dispute demands. ${ }^{33}$ Most disputes are over quality of goods, warranty, or effectiveness of delivery. ${ }^{34}$ If any judgment is to be correct, the court must evaluate the merits of the case in terms of trade practice. For example, under Section $44(1)$ of the Sales Act, a buyer's right to reject hinges on the jury's finding that goods delivered were less than the quantity contracted for. But trade practice allows leeway on length, width, and weight. ${ }^{30}$ Although

30. Section 63(3) of the Sales Act permits the seller, "if [the goods] cannot readily be resold for a reasonable price ... to offer to deliver the goods to the buyer, and, if the buyer refuses to receive them, [to] notify the buyer that the goods are thereafter held by the seller as bailee for the buyer. Thereafter the seller may treat the goods as the buycr's and may maintain an action for the price." Section $69(5)$ gives the buyer approximately the same remedy and authorizes the buyer to hold the goods pending return of the price or court decision.

31. Hearings, supra note 17 , at 6 . The major reason for frequent bankruptcies is that many retailers and cutters operate on short-term credit. Repayment depends on sales. A shift in the market affects retail sales; income may be minimal during a market decline. By the time the market returns to normal, the goods may either be unsaleable or the credit revoked.

32. Hessen, Arbitration-The Credit Executive's Ally 1 (1950).

33. Textile men have a very low regard for the jury system. INDUSTRY QUESTIONNAIRE. For a general discussion of the failings of jury trials in commercial disputes, sce Where Jury Trial Fails, 9 J. AM. Jud. Soc'Y 71 (1925). The drafters of the Revised Uniform Sales Act of 1941 recognized the inability of juries to handle technical mercantile disputes. Under Sections 59 to 59(D) factual questions in mercantile disputes were to go to three to five expert merchants for solution. See Note, 42 CoL. L. REv. 1372 (1942), for a discussion of this proposal.

34. Halstead, Arbitration Group Wins Recognition of Textile Trade, 1 Avv. J. 290 (1946); NFT Memorandun Opposing Assembly Bill Int. No. 10583 (1951).

35. Uniform Sales Act $\$ 44(1)$.

36. See, for example, the allowances for variation (tolerances) provided in the "specifications" in the Wortr StREet Rures 10-14 (rev. 1947). The leeway is allowed because, despite precautions, producers may have little control over the resulting product. Thus, goods will run slightly underweight in dry weather. See Presentation of Spectificstion G (1934).

Courts or juries might fail to give trade custom sufficient weight. For example, in Lowinson v. Newman, 201 App. Div. 266, 194 N.Y. Supp. 253 (1st Dep't 1922) the court 
trade practice could be introduced in litigation under the Sales Act, ${ }^{37}$ businessmen had to educate lawyers, who in turn tried to explain the often incomprehensible trade practice to the "impatient judge and ignorant jury."3s There was little likelihood that counsel's and witnesses' competing explanations were accurate, understood, or, if either, given sufficient weight. ${ }^{30}$

\section{Textile Arbitration in Operation}

Enforceable arbitration in the cotton, rayon, wool and silk industries is founded on Article 84 of the New York Civil Practice Act, passed in 1920.19 Under the Act, arbitration can take sole jurisdiction over any dispute arising out of a contract stipulating arbitration of all future disputes.11 Prior to the Act the Silk Association, now renamed the National Federation of Textiles, had provided its members with a voluntary arbitration tribunal set up in 1898.42 Since the passage of the Act, this tribunal became the locus for both silk and rayon arbitration. ${ }^{43}$ During the late twenties and early thirties a

by way of dictum said that delivery of ten extra pieces of cloth in a shipment in which a buyer ordered 2,000 pieces would have had much more force as grounds for rejection than a claim that the seller had no right to replace defective goods. Undoubtedly, under trade custom correctly interpreted, the buyer would not be allowed to reject the whole shipment because it exceeded the order by $1 / 2 \%$. Leeway to the extent of five to ten per cent is usually prescribed.

37. Uniform Sales Act $\$ 44(4)$ allows application of "any trade usage" to the question of quantity. Trade custom may also be introduced under $\S 44(3)$ to assist in the determination of whether goods are "of a different description." Trade custom is likewise relevant under $\$ 45(2)$ on material breach of installment contracts, $\$ 47(1)$ and (2) on reasonable time for inspection, and $\$ \S 48$ and 49 on acceptance and reasonable time.

38. IxDUSTRY QUESTTONNAIRE. Such practice used up valuable time of firms' executives-more time than is now consumed in arbitration even though an executive serves as an arbitrator. Communication to the YALE LAw Jounnal from a weaver, dated Jan. 7, 1952, on file in Yale Law Library.

39. HeSSEN, op. cit. supra note 32 , at 1 . Merchants corroborated this. Isidustny QUESTIONNAIRE.

40. N.Y. Crv. Prac Act, Art. 84, § 1448. See further President's Retort, 2 Ang. J. 1 (1947).

41. N.Y. Crv. Prac. ACr $\$ \$ 1448,1450$ and 1461. At common law such clauses were revocable. Sayre, Development of Commercial Arbitration Low, 37 YALE L.J. 595, 598 et seq. (1928). On revocability at common law, see Duns \& Dissond, Cosmercial ArniTRATTON 9-10 (1922). For studies of common law and statutory arbitration see Cuhen, The Law of Comnercial Arbitration and the Newi York Statute, 31 YaLE L.J. 147 (1921); Sturges, Conaterctal Arbitrations and Awards (1930) kussim.

42. Blunt, AN Arbitration Workshop 4 (1939). But this procedure was not too successful. Between 1900 and 1915 the Silk Association decided only 49 disputes. Arortration of the Silk Assoctation of Axrerica 7-20 (1915).

43. Blunt, op. cit. supra note 42, at 8 . Since many rayon merchants had been or still were engaged in the silk business, it was natural for them to have the sills tribunal handle their arbitration. Member organizations include the Silk Association and the National Rayon Weavers Association. The NFT is also used exclusively by members of the Tex- 
textile depression induced the rest of the textile industry to arbitrate its disputes. ${ }^{44}$ Thus, in 1930 cotton formed the General Arbitration Council whose facilities came into industry-wide use after 1935.45 In 1930 wool began to arbitrate its disputes through the American Arbitration Association, ${ }^{40}$ which, unlike the other two tribunals, is a nationwide organization handling labor, commercial, and international controversies for various industries as well as private disputes. ${ }^{47}$

\section{Jurisdiction Given By Contract}

Each arbitration tribunal takes jurisdiction by virtue of an individual textile contract, and its authority is derived wholly from the arbitration clause therein. ${ }^{48}$ In contrast to litigation, arbitration meets few jurisdictional barriers. Jurisdiction is not affected by diversity of citizenship or inability to get personal service on one party, since contracts stipulate jurisdiction in New York, and all tribunals' rules provide for service by mail. ${ }^{40}$ The operative clause granting jurisdiction is usually worded:

tile Distributors Institute, the rayon converters' association. Communication to YALE Law Journal from Hilda Wiedenfeld, Executive Secretary of the TDI, dated Feb. 28, 1952, on file in Yale Law Library.

44. Communication to the Yale Law Journal from a broker, one of the founders of the General Arbitration Council for cotton disputes, dated Dec. 27, 1951, on file in Yale Law Library. Textiles were a sick industry through much of the $1920^{\prime} \mathrm{s}$. BADER, op. cit. supra note 9, at 98,113 . Widespread breach plus aversion to litigation caused anarchy in the industries. Communication from a broker, supra. The cliché of the times was "sue me."

45. Halstead, supra note 34, at 291. Communication to the YALE LAw Journal from a broker, one of the founders of GAC, dated Dec. 27, 1951, on file in Yale Law Library. At the same time that the tribunal was formed, cotton textile trade associations tried to codify trade practices. See Definitions of FaIr Trade Practices 1-12 (1931). By 1935 a fairly satisfactory body of trade law had been promulgated. See WORTH STREEt RULEs (1935) (final draft). It was only then that use of arbitration on an industry-wide basis began. Communication from a broker, supra.

46. Kellor, American Arbitration 173 (1948).

47. Id. passinn; President's Report, 2 ARB. J. 1 ef seq. (1947).

48. aAA Commercial arbitration Rules ii (rev. 1952); GAC Organization, Procenure and Rules 4 (1949); Rule 2, Arbitration Rules of the NFT (rev. 1949). This is true of all types of arbitration in which parties use an arbitration clause in their contracts. Kellor, American Arbitration 66-7 (1948).

Where contracts do not have arbitration clauses, the tribunals allow arbitration by voluntary submission after a dispute arises. Rule $8 A A A$, Rule 5 GAC. But this device is seldom used since most contracts stipulate future arbitration.

49. See Rule 39 AAA, Rule 1 GAC, Rulc 25 NFT. Rule 39 AAA is typical:

"Each party to a submission or other agreement which provides for arbitration under these Rules shall be deemed to have consented and shall consent that any papers, notices or process necessary or proper for the initiation or continuation of an arbitration under these rules and for any court action in connection therewith 
"Any controversy arising under, or in relation to, this contract shall be settled by arbitration ... held in the City of New York in accordance with the laws of the State of New York and the rules then obtaining of the [tribunal named]."50

This is common phraseology although parties may stipulate any variation they desire. ${ }^{51}$ Specific reference to a tribunal's rules incorporates their substance in the contract.52 These rules preclude later court interference with arbitration procedures. ${ }^{53}$

or for the entry of judgment on any award made thereunder may be served upon such party (a) by mail addressed to such party or his attorney at his last known address. ..."

Substituted service is permissible under the arbitration statute. N.Y. Cn. Prac. ACt $\$ 1450$. Courts have consistently upheld the tribunals' provisions on service by mail. Sce, e.g., Merger Fabrics, Inc. v. Coill-Shuman Ca., 74 N.Y.S.2d 76 (Sup. Ct. 1947); Bradford Woolen Corp. v. Freedman, 189 Misc. 242, 71 N.Y.S.2d 257 (Sup. Ct. 1947).

For analysis of the advantages of substituted service, see Korzenili, Confesicd Brcach of Contract Suits, 4 ARB. J. 171 (1949). While parties to most textile disputes have representatives in the state, service by mail is invaluable against out of state retailers and cutters.

50. GAC Rules p. 3-4. The standard arbitration clause recommended by the AAA is similar. AAA Rules p. i.

51. Each tribunal recognizes the power of parties to make contracts which call for procedures substantially different from those provided in its rules. Rule 13 AAA allows parties to choose arbitrators as provided in their contracts rather than by the tribunal's panel system. In wool, which uses the AAA, many contracts evidently do stipulate varying methods of selecting arbitrators.

52. Rule 1 AAA states that AAA Rules are part of any clause stipulating AAA arbitration. See, e.g., Bradford Woolen Corp. v. Freedman, 189 Misc. 242, 71 N.Y.S.2d 257 (Sup. Ct. 1947).

53. Where the contract incorporates the rules of a tribunal, courts may not intervene during arbitration to correct a breakdown in procedure. For example, although courts are empowered to intervene if parties fail to appoint arbitrators, N.Y. Crv. PrAc. Act $\$ 1452$, the tribunals' rules now handle such contingencies. See Rules 12, 13 A.A.A; Rulc $6 G A C$; Rule 6 NFT. AAA directs the administrator to appoint an arbitrator if seven days have elapsed after the parties were requested to do so. NFT rules are similar. GAC allows the parties ten days. See also Rule $10 \mathrm{AAA}$ which permits the administrator to fix the locality for the hearing if parties disagree as to place. In effect procedures prevent undue obstruction by one party. But the main purpose of these rules is to prevent litigation. Hessen, Arbitration-The Credit Executive's Ally 3 (1950); Prcsident's Report, 2 ARE. J. 14 (1946). See generally Braden, Sound Rules and Administrations in Arbitration, $\$ 3$ U. of PA. L. Rev. 189 (1934).

Courts will enforce the power of a tribunal to correct procedural brcakdewns in accordance with its rules. See, e.g., Epstein-Harris Mfg. Co. v. Belvedere Fabries Ine., 121 N.Y.L.J. 537, col. 7 (Sup. Ct. Feb. 11, 1949) (arbitrator's unavailability for two months permits the NFT to select a successor according to its rules); Bradford Woolen Corp. v. Union Knitting 14ills, 117 N.Y.L.J. 711, col. 7 (Sup. Ct. Feb. 21, 1947) (A.AA administrator has power to select the place of arbitration if the parties do not agree on the place within seven days of the demand for arbitration). 


\section{Invoking Arbitration}

A demand for arbitration made upon the stipulated tribunal starts the arbitration process. ${ }^{54}$ If jurisdiction is contested, courts will compel arbitration ${ }^{55}$ unless either the arbitration clause or the whole contract is invalid. ${ }^{50}$ Questions of jurisdiction are waived if the issue is not joined promptly. ${ }^{\text {t7 }}$

Litigation over the validity and operative effect of the arbitration clause is infrequent and easily avoided since courts uphold the standard clause used in textiles. ${ }^{58}$ But courts must be satisfied that the contract has been accepted. ${ }^{59}$ Courts have denied arbitration of disputes over price if ceiling

54. Rule $7 A A A$. Rule $7(a)$ provides for a demand on the other party dircetly by written notice containing a statement of the nature of the case, the amount involved, and the remedy sought. Rule $7(b)$ provides for initiating arbitration by a demand on the tribunal itself. Two copies of the contract must be filed with the Administrator. The other party may, but need not, file an answer.

GAC and NFT provisions are similar. Under future contracts, a demand alone is sufficient. Rule 2 NFT. Submissions are necessary in the absence of a future contract. Rule 5 GAC. Once demand is received, the tribunal notifies the parties of the request, encloses the folio on rules, and asks for prompt selection of arbitrators. Rule 3 NFT.

55. N.Y. CIv. PRAC. ACT $\S 1450$. The petitioner must give the opposing party eight days' notice. Such notice, like all other papers, may be served by mail under the tribunal's rules. See note 49 supra.

- 56. N.Y. CIv. PRAC. ACT $\$ 1451$ permits a party to move for a stay of arbitration. Likewise, a party may oppose a petition to enforce arbitration under N.Y. Civ. PrAC. ACT $\S 1450$.

57. N.Y. Civ. Prac. Act $\S 1458-2$. This and N.Y. Civ. Prac. Act $\$ 1461$ bar attacks on contracts and jurisdiction in a proceeding for confirmation of the award if: (1) The party took part in the arbitration process despite the insufficiency of notice. Sec, e.g., Junior Miss Dress Corp. v. H. J. Stotter, Inc., 100 N.Y.S.2d 271 (Sup. Ct. 1950) ; Nelson v. Bestform Knitwear Corp., 87 N.Y.S.2d 353 (Sup. Ct. 1941); (2) The party was served a notice of demand for arbitration stating that the validity of the contract must be litigated within ten days. See, e.g., Stafford International Corp. v. Hartman Hosiery Ca., Inc., 89 N.Y.S.2d 172 (Sup. Ct. 1948). Ordinarily the tribunal in sending notices will include a ten day limit and thus force parties either to litigate promptly or waive the issue. But in Onondaga Silk Co., Inc. v. Roseville Frocks Inc., 194 Misc. 326, 86 N.Y. S.2d 154 (Sup. Ct. 1949) the NFT notice failed to set a ten-day limit and the award was subsequently vacated on the ground that no contract existed.

58. These clauses are commonly enforced. Communication to the YALE LAW Journal. from W. P. Fickett, President of the Textile Fabrics Association, dated Jan. 11, 1952, on file in Yale Law Library. For methods of preventing litigation on arbitration clauses, see Szabad, Specific Acceptance of Arbitration Clanses, 4 Arb. J. 139 (1949).

Jurisdiction will be denied on the ground of defective arbitration clauses: (1) Under N.Y. CIv. Prac. Acr $\$ 1449$, where future disputes clauses are not in writing, Grutz v. Oltarsh, 115 N.Y.L.J. 130, col. 7 (Sup. Ct. Jan. 10, 1946), cf. Tanenbaum Textile Co., Inc. v. Schlanger, 287 N.Y. 400,40 N.E.2d 225 (1942) (an invoice stamped with an arbitration clause was held ineffective since it was sent after delivery); (2) Where the arbitration clause is hidden. Compare Pedigree Fabrics, Inc. v. Colleen Lingerie, Inc., 122 N.Y.L.J. 1335, col. 2 (Sup. Ct. Nov. 22, 1949), with Cohen \& Sons Co. v. Lasky, 123 N.Y.L.J. 345, col. 1 (Sup. Ct. Jan. 27, 1950).

59. Airedale Worsted Mills, Inc. v. Bonnie Classics, Inc., 198 Misc. 259, 98 N.Y. S.2d 353 (Sup. Ct. 1950). Cf. Fabriton Corp. v. Lester Martin \& Co., Inc., 300 N.Y. 
price cuts across the stipulations of the contract. ${ }^{60}$ Other issues raised by the contract, such as cancellation and rescission, must be settled by arbitration itself. ${ }^{61}$ And arbitrators rather than courts are empowered to determine the enforceability of claims brought after the running of limitation periods specified in contracts. ${ }^{62}$

\section{Arbitrators and Arbitration Boards}

Arbitrators are in complete charge of each arbitration. They set the date for the hearing, grant postponements, call witnesses, cross-examine parties, and inspect goods. ${ }^{63}$ They may decide questions of law although they are not bound to adhere to substantive law-a risk parties take when they accept

476, 88 N.E.2d 659 (1949) in which the court denied arbitration under an unsigned broker's salesnote hecause the purchaser had confirmed a sales cuntract containing nu arbitration clause.

N.Y. Crv. Prac. ACT $\$ 1449$ does not require the signing of the arbitration clause itself. See Piedmont Shirt Co. v. Golden, 117 N.Y.L.J. 1807, col. 7 (Sup. Ct. MFay \&, 1947) (arbitration ordered in the face of an unsigned NFT arbitration clause).

Despite the absence of a signature, courts have often used the party's performance to establish acceptance. Thus in Ramser v. Cohn-Hall-Mars Co., 73 N.Y.S.2d 210 (Sup. $C_{t}$ 1947), the arbitration agreement was enforced since the buyer unpaclied the goods. Accord, Turner-Halsey Co. v. A. M. Grossman, Inc., 122 N.Y.L.J. 317 , col. 3 (Sup. Ct. Aug. 24,1949 ) (salesnote which provided for GAC arbitration was ratified by retention of the salesnote, acceptance of the goods, and the sending of a check). But cf. Aljo Fabrics, Inc. v. Princeton Rayon Corp., 119 N.Y.L.J. 657, col. 2 (Sup. Ct. Feb. 20, 1948) (trade custom inapplicable since the salesnote provided only for acceptance in writing).

60. In Matter of Kramer \& Uchitelle, Inc, 28S N.Y. 467,43 N.E. 28493 (1942) the court stayed arbitration on the ground that establishment of a ceiling price lower than contract price had abrogated the contract. But cf. Knickerbocker Textile Corp. v. Elias Bros., Inc., 275 App. Div. 915, 90 N.Y.S.2d 498 (1st Dep't 1949). A lower court had ordered arbitration although the price stipulated in the contract was to be the OPA ceiling and ceilings had been discontinued. Arbitrators then held the price too uncertain for enforcement and the court refused to vacate their award.

61. Courts construe these as cases "related to and arising out of the contracts." As such, textile contracts give jurisdiction to arbitration. See, e.g., Alpert v. Admiration Knitwear Co., Inc., 278 App. Div. 841, 104 N.Y.S.2d 309 (2d Dep't 1951) (cancellation); Samuel Kaplan \& Sons, Inc. v. Fascinator Blouse Co., Inc., 70 N.Y.S.2d 8 (Sup. Ct. 1947) (rescission).

62. In Gramil Weaving Corp. v. A. M. Brettler \& Co., Inc., 121 N.Y.L.J. \&\&, col. 2 (Sup. Ct. March 10,1949), the court allowed the arbitrators to decide the effect of a ten day limitation of claims imposed by the contract. Accord, Rhea Mfg. Co. v. Associated Lace Co., 117 N.Y.L.J. 1735, col. 1 (Sup. Ct. Miay 3, 1947) (five day claim limitation specified in the contract). Cf. Gay Junior Dresses, Inc. v. Cohen, 115 N.Y.L.J. 107, col. 6 (Sup. Ct. Jan. 9, 1946) (party deemed guilty of laches because he neglected to demand arbitration).

63. N.Y. CIV. PRAC. ACT $\$ \$ 1454$ and 1456 give very broad powers to arbitraturs. Rules of the tribunals, however, limit these powers to some extent. See Rules 20-35 AAA; Rules 9, 12,13,15 NFT; Rules 9, 17 GAC. The tribunal itself may set the date for the hearing although the time must be convenient to all arbitrators. 
arbitration clauses. ${ }^{64}$ Arbitrators decide each dispute on its individual facts, rather than on precedents. ${ }^{65}$ Neither awards nor records of previous arbitrations are available.

The technical nature of the issues in the textile field has necessitated the use of men well versed in the operations of the industry. As a result arbi trators in the rayon and cotton tribunals are invariably textile merchants. ${ }^{00}$ Parties themselves make an effort to choose men who are expert on the particular issue. ${ }^{67}$ However, unlike the other two tribunals, some AAA arbitrators on textile disputes are outsiders-lawyers for example. .8 $^{\text {88 }}$

A new arbitration board is constituted for each case. Cases are usually heard by three arbitrators, although one arbitrator may hear small claims. ${ }^{00}$ The General Arbitration Council (cotton) and the National Federation (rayon and silk) both employ the tripartite system of selection. ${ }^{70}$ Each party to a dispute picks one arbitrator from either a panel list provided by the tribunal or the industry at large. ${ }^{71}$ This choice is limited only by the other party's

64. See Denis-Marcus, Inc. v. Leonard Sportswear Corp., 122 N.Y.L.J. 958, col. 3 (Sup. Ct. Oct. 24, 1949) ; Kellor, Arbitration in Action 7 (1941); Arbitration a Part of Jildicial Administration, 9 J. Am. JUd. Soc'y 69 (1925). Rule 17 NFT states that arbitrators have the right to consult counsel but are not bound by their opinion.

Power to deviate from the law may be limited by the submission agreement of the parties. Of course, arbitrators must observe the duties set forth in the Arbitration Statute. For example, they must accept all pertinent evidence offered.

65. BLuNT, op. cit. supra note 42 , at 12 . Interviews with merchants and officials indicated that few arbitrators ever desire to find out how issues have been construed in past decisions. Arbitrators and parties alike prefer to settle each case on its individual facts. INDUSTRY QUESTTONNAIRE.

66. INDUSTRY QUESTIONNAIRE. Rule 4 NFT specifically restricts selection of arbitrators to members of the industry. Lawyers agree that the exclusive use of textile merchants is of great benefit. LAwYERS' QUESTIONNAIRE.

67. In their selection of arbitrators, merchants are most concerned with expertise. 46 merchants listed this as the primary consideration. INDUSTRY QuestionNaIre.

68. Lawyers criticize use of outsiders in woolen arbitrations. LAWYERS' QUESTIONNAIRE Although outsiders may be arbitrators in woolen disputes, woolen experts are included in the AAA panel list and they are frequently chosen. INDUSTRY QUESTIONNAIRE,

69. Rule 4 NFT provides for arbitration by a three man board unless otherwise agreed to by the parties. Rulle $12 A A A$ provides for one man arbitration of commercial disputes, but Rules 13,14 AAA recognize most merchants' preference for three man boards and provide a system whereby they may be appointed. Rule 6 GAC allows one, three or five man arbitration. However, if parties cannot agree on one man, the three man board is used.

For small claims, NFT does not provide one man arbitration. Rulc 6(c) GAC gives the Secretary discretion to use one man arbitration for claims under $\$ 500$.

70. Rule 6 NFT; Rule 6(b) GAC. Textile merchants prefer this system of selection to mutual selection of each arbitrator. Of 50 cotton merchants, 44 prefer to choose their own arbitrator. Of 50 rayon and silk merchants, 41 prefer to choose their own arbitrator. INDUSTRY QUESTTONNAIRE.

71. See Rules 5, 6 NFT; Rule 6 GAC. In both tribunals, panels number upwards of 300 names and are restricted to textile men categorized according to trade. At least one 
objection to the arbitrator on grounds of partiality. ${ }^{22}$ These two arbitrators then select a third who serves as chairman.

The panel system of selection, used by the American Arbitration Association (wool) ${ }^{73}$ employs bilateral choice. Using a panel list prepared by the tribunal, each party names panel members in order of preference. Preferences are matched and two of the three arbitrators are selected. These two bipartisan arbitrators then choose the third arbitrator.

\section{The Arbitration Hearing}

Once at hearing, the arbitration process is close to the end. It may have taken a month or a year to get this far, but hearings will seldom consume more than a couple of hours and awards are made within 24 hours. ${ }^{74}$ Speed is primarily attributable to the fact that expert arbitrators are not bound by strict rules of procedure or evidence. ${ }^{75}$ Furthermore, they know what information is important and they find it quickly.

The hearing is concerned primarily with the parties' conduct in the light of trade custom. Custom delineates the acceptable patterns of performance and the reasonable expectations of parties to contracts. Assume a dispute between a mill and a converter over allegedly defective cloth. Since not all imperfections in textile products are considered defects, arbitrators would have to construe trade practice in order to decide the controversy..$^{70}$ Even if a defect

arbitrator must be chosen from the panel list. Rule 4 NFT; Rule 6 GAC. Usually more than one will be a panel member. G.AC Rules p. 7. But many textile merchants would gu further. 46 of 92 merchants want choice to be limited to panel members. Invusni: QUESTIONNAIRE.

72. All three tribunals call for disqualification of "interested" arbitrators. Rule 11 AAA; Rule 6 GAC; Rule 4 NFT. Rules 8,14 NFT make arbitrators swear in writing that they have had no communication with either party regarding the controversy. Any communication is ground for disqualification. Under N.Y. Crv. PrAc. Act $\$ 1462$ a court must vacate an award procured by corruption or fraud, or "where there was evident partiality or corruption in the arbitrators."

The system of objecting to another's choice of arbitrator is elaborate. See Rule $\sigma$ $G A C$. Objection may be very difficult to support. But, with few exceptions, textile men will object where grounds are valid. INDUSTRY QUESTIONANArE.

73. AAA restricts choice to panel members. Rule $12 A$ AA. But any man who is mutually acceptable to both parties may be chosen even if he is not a panel member. Of 91 merchants who arbitrate in the rayon and cotton tribunal, only 15 would prefer the AAA panel system. But see Rule $13 A A A$ which allows choice by the tripartite system where the parties so stipulate in the contract. Many woolen merchants in fact prefer the tripartite method. IndustrY Questionsaire.

74. Interviews with J. Noble Braden of the AAA, Irene Blunt of the NFT, and H. A. Sherman of the GAC.

75. GAC Rules p. 4 (1949). However, the arbitrators and the tribunal are bound to follow the procedures which are provided in their rules. Raycrest Mfills, Inc v. A. M. Pearlman, Inc, 121 N.Y.L.J. 2299, col. 5 (Sup. Ct. June 30, 1949).

76. For example, differences in shading of rayon gouds, attributable to difference in yarn dyeing by the fiber manufacturers, are not considered defects. Typies. Raru: Civi- 
exists, whether the whole order may be rejected depends on other elements of trade custom. Unlike the Sales Act, trade custom recognizes degrees of non-conformity, allowing different remedies depending on the seriousness of the imperfection. ${ }^{77}$ Standards of non-conformity vary according to the type of cloth ordered, ${ }^{78}$ the description under which the goods were purchased (first quality, second quality, by sample, as are), ${ }^{70}$ and the use for which the cloth was intended. ${ }^{80}$ These issues may be complicated by dispute on acceptance, delivery, or terms of the contract. Since the expectations of the parties are based on their contracts, arbitrators must know the trade meaning of phrases commonly employed in market transactions-terms such as "prompt delivery," "tailings," "gas runs," and "vat dye."

But the fact that arbitrators are textile merchants does not guarantee uniform interpretation of the facts; trade custom itself is often amorphous and unsettled. ${ }^{81}$ To help provide uniformity and certainty, cotton has codified some elements of its trade customs. ${ }^{82}$ Known as the Worth Street Rules, this

TRACTS on file in Yale Law Library. "Besides normal irregularities natural to the fibers used, a reasonable number of manufacturing defects must be expected." TExTILE Distributors Institute, Standards For the Examination of Finished Goods 2 (1950 cd.).

77. Under $\$ 69$ of the Uniform Sales Act, all of the buyers' remedies for breach of warranty become available when requisite non-conformity is established. The buyer may elect any remedy, including rejection of the whole shipment, $\S 69(1)$ (d), for a relatively minor defect as well as for a major one. Under textile arbitration, however, minor nonconformity permits only lesser remedies. WORTH StREet Rules 10-14 (rev. 1947), for example, allow only recoupment in diminution of price for minor deficiencies in cotton.

78. Under the four different "Specifications" of the WORTH STREET RuLes which cover tolerances for different groups of cotton fabrics, percentage allowances for wcight and width vary according to the type of cloth. WorTr STREET RulEs 10-17 (rev. 1947).

79. For example, if goods are bought "as are," the buyer waives all redress for patent or latent defects. Worth StreEt Rules 30 (rev. 1947).

80. See Worth Street Rules 37 (rev. 1947); Textrle Distrinutors Institure, Standards For The Exanination of Finished Goods 1 (1950 ed.).

81. INDUSTRY QUESTIONNAIRE.

82. The effort to achieve a codification satisfactory to all trades in the cotton indus try took ten years. Weavers and converters made the initial step in 1930. In 1931 they published a small booklet outlining basic trade terms and their meanings. Derrinitrons of Fatr Trade Practices (1931). In 1932, they recommended eight uniform Salesnote Clauses which covered matters of performance-time of acceptance and the likc. In 1934 with the help of textile brokers, they proposed the Standard Cotton Textile Salesnote, covering matters of performance and rights in disputes, and the first of the cotton goods Specifications. See Presentation of the Standard Cotton Textile Salesnote (1934); Presentation of Specticication G (1934). After going through five preliminary drafts, the final draft of the Wortm STREET RuLes incorporating the Salesnote and Specifications was adopted by eleven different cotton trade associations in 1936. Since then the Wormi StreEt Rules have been revised in 1941 and again in 1947. There are indications that the rules need revision once more. Communication to the YALE LAW Journal from a broker, dated Dec. 27, 1951, on file in Yale Law Library. The advance of technology and chemistry has significantly changed the quality of production while trade meaning has not kept pace. Ibid. 
codification contains "specifications" covering quality standards for staple cloths. ${ }^{33}$ For finished cloth-grey goods which have been processed-the Worth Street Rules suggest methods for testing colorfastness, tensile strength, and shrinkage. ${ }^{84}$ Furthermore, widely used trade phrases are given definitions so that parties have less opportunity to dispute the meaning of their contracts. $^{85}$ For example, goods ordered as "run of the mill" include by definition the normal proportion of gradings produced by the seller before the goods are classified as first quality, seconds, or inferior. ${ }^{80}$ Finally, these rules contain the Standard Cotton Textile Salesnote covering passing of title, terms of collection and credit, delivery, cancellation, rejection, allowances, defaults in payment, casualty, and other contingencies. ${ }^{87}$

Despite inadequacies and incomplete coverage, ${ }^{88}$ cotton's codified customs are useful in at least three ways. First, they guide arbitrators who may apply

83. There are four different Specifications. Together they encompass nearly every type of staple cloth. See the Worta Street Rules 9 (rev. 1947). Specifications cover tolerances allowed in quantity delivered, in weight of the cloth, and in width of the fabrics. They also include deficiency limits on numbers of thread ends and other technical aspeets which only a textile man can understand. Finally these Specifications include degrees of conformity on which are based the rights of buyers to seek allowances, cancel, or reject the goods. See, for example, Specification F.F., Worth Street Ruzes 10-11 (rev. 1947).

84. Worth Strekt Rules 43-63 (rev. 1947). These are only suggestions since they have not been adopted by all trades. Id. at 43 .

85. Worth Street Rules 30-7 (rev. 1947).

86. Worth Street Rules 34 (rev. 1947). "Run of the mill" is cited as an illustration because the rayon trade definition of the same word differs from that in cotton.

87. The Salesnote, found in the Worth Streer Rules 4-8 (rev. 1947) and incorporated by reference in most cotton textile contracts, is of great importance to parties and arbitrators in that it defines the rights of parties on matters of title, credit, time for rejection and the like. For example, the Salesnote stipulates the meaning of reasunzble time for the discovery of latent and patent defects on which hinge the right to seek allowance or replacement. WORTH STREet RULEs 6 (rev. 1947). When an arbitration award is attacked in court, judges refer to the Salesnote to ascertain the validity of an arbitrator's determination. For example, in Campe Corp. v. Pacific Mills, 87 N.Y.S.2d 16 (Sup. Ct. 1949) the court decided that under the Salesnote a buyer had the right to reject goods without paying damages. Therefore, the court, ignoring the cardinal rule that it should not review the merits of an award, vacated a GAC award which forced the buyer to accept the goods at a discount. On appeal, the Appellate Division, looking to the Salesnote, held that the arbitrators could have found that time for rejection had expircd; the award, therefore, was confirmed. Campe Corp. v. Pacific Mills, 275 App. Div. 634, 92 N.Y.S.2d 347 (1st Dep't 1949).

88. It is quite evident from interviews and questionnaires that the WOarn STREET RuLes have many loopholes. (1) Many of the existing definitions are inadequate. For example, definitions of first quality or run of the mill depend on a specific mill's record. These two terms are extremely variable. Merchants believe that with new machinery, standards of quality should be raised over those provided in the late 1930's. (2) Mferchants also point to the failure of the rules to cover many issues raised in disputes. Inousny QUESTIONNAIRE. Specifically, textile men report that the rules overlook finished goods and finishing qualities. Ibid. Correcting these deficiencies, however, is extremely difficult because textile disputes present an infinite number of variables. 
these rules directly or by analogy if the specific point is not covered.80 Second, the code, by informing the parties of the rules likely to govern decision, prevents disputes and limits the area of controversies that should go to arbitration..$^{00}$ Finally, these rules bring uniformity into trade contracts, and thus help to ensure that all merchants no matter how small or powerful will be given roughly the same benefits. ${ }^{01}$

Although the other textile industries have no codification comparable to the Worth Street Rules, they have made attempts to provide uniformity and prevent disputes. Wool uses the Mutual Adjustment Bureau of the Garment Trades for a binding test of quality before payment is made for the delivery. ${ }^{.2}$ Rayon, however, evidently makes little similar use of its testing bureau. Moreover, rayon trade customs, which are understood and in part written, have not been accepted by both buyers and sellers. ${ }^{93}$ Instead individual rayon contracts stipulate conditions of sale and remedies available to parties in disputes. ${ }^{94}$ But there is no uniformity, and the contracts are often much more one-sided than their counterparts in cotton. ${ }^{95}$ Moreover, on quality and questions of degrees of non-conformity these contracts are silent. ${ }^{.00}$ In most rayon disputes, therefore, arbitrators have little guidance in deciding the merits of each case.

\section{INDUSTRY QUESTIONNAIRE.}

90. In the words of the Presentation of the Standard Cotton Textile Salesnote 1 (1934), the rules were ". . . calculated to produce fewer misunderstandings, fewer arbitrations, fewer lawsuits, and fewer losses." In this the Rules have succecded. 48 out of 56 cotton merchants consider the WORTH STREET RuLES a key to cotton arbitration's success. INDUSTRY QUESTIONNAIRE.

91. Uniformity proceeds from the fact that the Standard Salesnote and the Specifications in the WORTE STREET RULES are incorporated by reference in virtually evcry cotton contract.

92. INDUSTRY QUESTIONNAIRE.

93. INDUSTRY QUESTIONNAIRE. Some men in rayon and silk think that they have a body of rules comparable to those that exist for cotton. Weavers and converters are in substantial agreement on trade custom, and the rayon converters' association has progressed towards codifying customs applicable to finished goods. Sec TExTiLE DisTr1BUTORS INSTTTUTE, Definitions AND Trade Customs. 'The association has also recommended standards for examination of finished goods. However, these are not accepted by buyers. See Textile Distributors Institute, Standards for the Examination of FinISHED Goons 1 (1950 ed.). In silk the situation is similar. Members of the industry are attempting to define trade practice, but, as in rayon, there is no sign that such definitions are mutually acceptable to buyer and seller. See TExtrle Disrrinutors INSTirute, BuL* LETIN No. 1573, Jan. 1, 1952.

94. Typical Rayon Contracts on file in Yale Law Library,

95. On the matter of delivery by the converter, for example, the WorTu STrEet Rules give the seller three days' grace. Worth StREeT Rules 33 (rev. 1947). But rayon converter-cutter contracts often stipulate that the cutter must accept goods delivered 10, 15 , or even 30 days after date specified. Typical Rayon Contracts on file in Yale Law Library.

96. Ibid. 
Awards

Flexibility of remedy provided in these tribunals' rules aids arbitrators in their task. All three tribunals authorize arbitrators to use any remedy which in their estimation is fair and equitable. ${ }^{97}$ Specific performance is expressly allowed. ${ }^{9 s}$ The GAC (the cotton tribunal) and the NFT (the rayon and sill tribunal) further stipulate that arbitrators may also require acceptance or replacement of goods, fix allowances for defective merchandise, declare a contract breached in whole or in part, and (or) award money damages. ${ }^{93}$ Thus one party need not gain his entire claim simply because the balance of equities leans toward his side. ${ }^{100}$ For example, if a converter desired to reject defective cloth he might receive instead an award requiring him to accept the cloth subject to an allowance for the defect. ${ }^{101}$ Such a decision might be reasonable if the converter's claim was justified but he had been tardy in giving notice of rejection.

\section{Courts and Awards}

If the losing party in arbitration refuses to obey the award, the winning party can get a court order confirming the award, which gives it the same force as a judgment at law. ${ }^{102}$ If the court finds the arbitrators partial ${ }^{103}$

97. Rule 42 AAA; Rule 14 GAC; Rule 19 NFT.

One court thought that "fair and equitahle" was inconsistent with the contractual requirement of "full settlement of claims." Campe Corp. v. Pacific Mills, 87 N.Y.S.2d 10 (Sup. Ct. 1949). But this view was repudiated by the Appellate Division. Campe Corp. v. Pacific Mills, 275 App. Div. 634, 92 N.Y.S.2d 347 (1st Dep't 1949).

98. Rule 42 AAA; Rule 14 GAC; Rule 19 NFT. See Forge Mills, Ine v. Foster Bros. Sportswear Co., 117 N.Y.L.J. 1877, col. 7 (Sup. Ct. May 13, 1947).

99. Rule 42 AAA; Rule 14 GAC; Rule 19 NFT. Courts have regularly overruled - parties' contentions that arbitrators exceeded their authority in awarding these remedies. See, e.g., Matter of Morris White Fashions, Inc. v. Susquehanna Mills, Inc., 295 N.Y. 450,68 N.E.2d 437 (1946) (damages awarded on only one part of claim); Rutgers Fabrics Corp. v. Corday Jrs., Inc., 121 N.Y.L.J. SS4, col. 1-2 (Sup. Ct. Alarch 10, 1949) (acceptance directed).

100. Industry QuestTonnaire.

101. Thus, in Campe Corp. v. Pacific Mills, 87 N.Y.S.2d 16 (Sup. Ct. 1949), res'd, 275 App. Div. 634, 92 N.Y.S.2d 347 (1st Dep't 1949) Campe had rejected cloth. The only issue was whether the goods conformed to the agreement. The arbitration award read "Campe Corporation shall accept the balance of the uncut yardage at the contract price, less a discount of six cents per yard." 87 N.Y.S.2d at 19. The Supreme Court vaeated the award under N.Y. Crv. PrAC. ACT $\$ 1+62$, but the Appellate Division reversed, holding the award to be conclusive.

102. N.Y. CIv. PRAC. ACT $\$ 1466$. A motion to confirm must be made within one year after the award is made. N.Y. Crv. "PrAC. ACr $\$ 1461$. Notice to an adversary of the motion may be delivered by mail. N.Y. CIv. PRAC ACr $\$ 1450$ (amended 1944).

103. N.Y. Crv. PrAC. ACr $\$ 1462-2$. Because of the centralization of these industries and the constant personal association of textile merchants, partiality will not be found where the party is merely acquainted with the arbitrators. Reinsdorf Co., Ine. v. Bergen 
or derelict in conducting hearings, ${ }^{104}$ or if it finds the award indefinite, ${ }^{100}$ it may vacate the award on the opponent's crossmotion. ${ }^{100}$ Otherwise the award will be confirmed. Courts will not make a decision on the merits and arbitrators are allowed to exercise their judgment without interference. ${ }^{107}$ The recent court decisions which deviate from these rules were without exception reversed. ${ }^{108}$ And few textile awards are upset by the courts on any grounds. ${ }^{109}$ Attacks on awards appear to be induced either by dissatisfaction

Fabrics Corp., 121 N.Y.L.J. 156, col. 1 (Sup. Ct. Jan. 13, 1949). Even a close community of interest may not be sufficient to induce a finding of partiality. St. George Textile Corp. v. Brookside Mills Inc., 85 N.Y.S.2d 621 (Sup. Ct. 1948) (arbitrator of winning party indebted to a corporation whose president was sales agent of the winning party) ; but cf. Gramil Weaving Corp. v. Raindeer Fabrics, Inc., 121 N.Y.L.J. 669, col. 4 (Sup. Ct. Feb. 23, 1949) (arbitrator was a salesman for a company which had previously done business with a party, and was in charge of obtaining orders from that party's company).

It is striking that all cases on partiality arose under the tripartite system of selection.

104. N.Y. Civ. Prac. ACT. § 1462-3. See, e.g., Samuel Kirshbaum Fabrics Corp. v. L. \& G Greenfield Inc., 80 N.Y.S.2d 443 (Sup. Ct. 1948) (award vacated because of failure to hear pertinent evidence) ; Raycrest Mills, Inc. v. A. M. Pearlman, Inc., 121 N.Y.L.J. 2299, col. 5 (Sup. Ct. June 30,1949) (GAC award vacated because arbitrators violated GAC rules by excluding counsel).

Other attacks have been made on alleged misconduct, but all have failed. Sce Hudson Fabrics, Inc. v. Susan Joan Frocks, Inc., 275 App. Div. 335, 89 N.Y.S.2d 59 (1st Dep't 1949) (power to make supplementary award upheld) ; Knickerbocker Textile Corp. v. Kingsley Fashions, Inc., 80 N.Y.S.2d 425 (Sup. Ct. 1948) (postponement for cause); Knickerbocker Textile Corp. v. Ginsberg, 119 N.Y.L.J. 468, col. 1 (Sup. Ct. Feb. 5, 1948) NFT exclusion of counsel in accordance with its rules).

105. N.Y. Civ. Prac. Act § 1462-4. See Arcola Fabrics Corp. v. Alco Blouse Co., Inc., 274 App. Div. 431, 84 N.Y.S.2d 378 (1st Dep't 1948). The statute also grants power to vacate where the arbitrators exceed the powers given to them by the submission. Samuel Kirshbaum Fabrics Corp. v. L \& G Greenfield Inc., 80 N.Y.S.2d 443 (Sup. Ct. 1948) (submission included a letter which arbitrators did not admit into evidence; award vacated). All other attacks made on these grounds have been unsuccessful.

106. N.Y. Crv. Prac. Act $\$ \S 1462,1462$-a. Power to modify or recommit did not exist at Common Law. Sturges, Commercial. Arbitrations ANd Awards $\$ \$ 369-70$ (1930).

107. See Campe Corp. v. Pacific Mills, 275 App. Div. 634, 92 N.Y.S.2d 347 (1st Dep't 1949).

108. Knickerbocker Textile Corp. v. Leifer Mfg. Corp., 103 N.Y.S.2d 782 (Sup. Ct. 1951), reo'd, 278 App. Div. 351, 105 N.Y.S.2d 200 (1st Dep't 1951); Campe Corp. v. Pacific Mills, 87 N.Y.S.2d 16 (Sup. Ct. 1949), rev'd, 275 App. Div. 634, 22 N.Y.S.Zd 347 (1st Dep't 1949); Hudson Fabrics Inc. v. Susan Joan Frocks, Inc., 275 App. Div. 335, 89 N.Y.S.2d 59 (1st Dep't 1949); Active Fabrics Corp. v. Rosedale Fabrics, Inc., 275 App. Div. 654, 86 N.Y.S.2d 153 (1st Dep't 1949) ; Springs Cotton Mills v. Buster Boy Suit Co., Inc., 121 N.Y.I.J. 750, col. 3 (Sup. Ct. March 1, 1949), revid, 275 App. Div. 913 , 89 N.Y.S.2d 609 (1st Dep't 1949) ; Arcola Fabrics Corp. v. Brenda Modes, Inc., 72 N.Y.S.2d 700 (Sup. Ct. 1947), rev'd, 273 App. Div. 891, 78 N.Y.S.2d 46 (1st Dep't 1948).

109. In the last five years there have been only about 30 attacks on the awards of New York textile tribunals. Of these attacks only six can be considered successful. In 
with the merits or by desire for delay. ${ }^{110}$ The total number of attacks has been minimal. ${ }^{111}$

\section{Evaluation of Textile Arbitration}

Merchants consider textile arbitration a success. ${ }^{112}$ On the whole it is a cheap, fast, and equitable system of settling disputes. ${ }^{113}$ Moreover, merchants consider arbitration vastly superior to litigation. ${ }^{114}$ The use of arbitration clauses in virtually all cotton, rayon, and silk contracts and in most wool

one GAC case the award was vacated because counsel was wrongly excluded. Raycrest Mills, Inc. v. A. M. Pearlman, Inc, 121 N.Y.L.J. 2299, col. 5 (Sup. Ct. June 30, 1949). In two NFT cases the award was vacated: once when arbitrators exceeded the submission; Samuel Kirshbaum Fabrics Corp. v. L \& G Greenfield Inc., 80 N.Y.S.2d 443 (Sup. Ct. 1948); and once on contract issues, Onondaga Silk Co., Inc. v. Roseville Frocks Inc., 194 Mfise. 326, 86 N.Y.S.2d 154 (Sup. Ct. 1949). In one NFT case the award was not confirmed (without prejudice) since the party should have had recourse to a supplementary arbitration hearing and not to court. Arcola Fabrics Corp. v. Alco Blouse Co., Inc., 274 App. Div. 431, 84 N.Y.S.2d 378 (1st Dep't 1948). In two more NFT cases questions of partiality were sent to referees for hearing and the awards were not confirmed. Atlantic Rayon Corp. v. Goldsmith, 277 App. Div. 554, 100 N.Y.S.2d 849 (1st Dep't 1950) (connection between winning party's counsel and his arbitrator); Gramil Weaving Corp. v. Raindeer Fabrics, Inc, 121 N.Y.L.J. 669, col. 4 (Sup. Ct. Feb. 23, 1949). Other attacks on 16 NFT awards, 4 GAC awards, and 4 AAA awards all failed.

110. See Active Fabrics Corp. v. Rosedale Fabrics, Inc, 275 App. Div. 654, 86 N.Y. S.2d 153 (1st Dep't 1949) (court finds attack based on dissatisfaction with awards); Stafford International Corp. v. Hartman Hosiery Co., Inc, 89 N.Y.S.2d 172 (Sup. Ct. 1948) (court characterizes attack as clearly dilatory).

111. Until 1946 only two GAC awards had been attacked in caurt and in both cases the award was confirmed. Halstead, supra note 34, at 291. In the AAA roughly only 6\%6 of AAA agreements and awards go to court for enforcement. KELLO, ARmimATIO: I:: Action $\&$ (1941). There are no figures on the percentage of NFT contracts or awards which find their way into the courts but it is apparently lov. Only one out of 130 textile merchants complained that there was too much recourse to the courts. INDUSTRY QUESTIONNAIRE

112. Of 128 textile merchants who expressed any feeling about the success or failure of arbitration, only 21 evidenced any dislike. INDUSTRY Questioxisire Ifany considered arbitration a "remarkable success." Most dissatisfaction was over isolated aspects of the system-method of selection of arbitrators, use of lawyers, or tendency to compromise. Only 4 expressed blanket dislike of arbitration. Ibid.

Lawyers with experience in arbitration in one or more of these tribumals all consider arbitration a success. LAwYERs' QUEstTONNAIRE.

113. Questionnaires gave merchants ample upportunity to criticize these aspects of arbitration. Of 130 merchants, at most a dozen feel arbitration is too expensive, possibly six feel too much time is consumed in arbitration to make it useful, and approximately a dozen are convinced that arbitration is unjust. INoustry Questronsaire.

114. INDUSTRY QUestionNaIRe.

Cotton $(G A C)$ : Of 58 merchants, 51 feel that arbitration is an advance over litigation. Nine of the ten merchants who dislike arbitration, see note 112 supra, admit that it is superior to litigation. Ibid.

Rayon, silk (NFT): Of 56 merchants, 49 feel that arbitration is an advance over litiga- 
contracts demonstrates arbitration's importance. ${ }^{115}$ Significantly, only occasional firms would omit arbitration clauses from their contracts in order to gain customers. ${ }^{116}$

\section{Speed}

At best textile arbitration takes one month, but more commonly it will require between two and three months. ${ }^{117}$ If a longer time is consumed, it is usually the fault of both parties. If parties desire a swift decision, they can complete the preliminaries-appointment of arbitrators, preparation of the case, and selection of a suitable date for hearing - within one month. ${ }^{118}$ Time may be unavoidably prolonged by last minute inability of a party, an arbitrator, or counsel to appear at the set time. And if both parties desire to use arbitration as a threat to gain a settlement, arbitration has as many delaying

tion. Eight of eleven merchants who dislike arbitration consider it superior to litigation. Ibid.

Wool $(A A A): 100 \%$ consider arbitration an advance. Ibid. Lawyers were asked if they thought textile men preferred arbitration to litigation. All said that merchants preferred arbitration. LAWYERS' QUESTIONNAIRE.

115. INDUSTRY QUESTIONNAIRE.

Rayon and silk: Of 42 merchants only one (a garment manufacturer) states that the bulk of his contracts do not stipulate arbitration. Rayon fiber manufacturers do not use arbitration. Ibid.

Cotton: Of 54 merchants only three (all large mills) state that the bulk of their contracts do not stipulate arbitration. Two of the three claim they never have had a dispute in which the desire for good customer relations did not bring a satisfactory settlement. The other merchant considers arbitration a "nuisance." Ibid. Ibid.

Wool: Of 13 merchants all report that most of their contracts stipulate arbitration.

116. InDUSTRY QUeSTIONNAIRE. Merchants were asked if a declining or rising market affected their desire to retain arbitration clauses in contracts. The great majority reported that market conditions have no effect. A few said that they would drop clauses in order to sell goods to cutters who prefer not to have arbitration clauses. But other sellers declared that a declining market period is precisely the time when they insist on an arbitration clause.

117. Ibid. Interviews with $\mathrm{J}$. Noble Braden of the AAA, Irene Blunt of NFT and H. A. Sherman of the GAC corroborate these figures. Average time is about 8 wecks in the GAC, 10 to 11 weeks in the AAA, and 17 weeks in the NFT. But these averages include prolonged cases in which parties get postponements while trying to settle privately.

118. The major delays between the demand for arbitration and the hearing are: (1) Time consumed in selecting arbitrators. The AAA and NFT allow 14 days. GAC allows 20. Rules 13,14 AAA; Rule 6 NFT; Rule 6 GAC. Despite the fairly long time allowed, these rules are rarely enforced strictly.

(2) Time consumed in scheduling a hearing. Unless both parties waive the waiting period after selection of arbitrators and before hearing, as much as five days in AAA, 14 days in NFT, and 10 days in GAC must be taken. Rule 20 AAA; Rule 9 NFI; Rulc 9 GAC. 
tactics as litigation. ${ }^{119}$ But arbitration differs from litigation in that, if one party so desires, a dispute may be resolved within a month or two. 100

Quick decisions in an industry plagued by fluctuating markets are the primary requirement of textile merchants. Speed minimizes chances of bankruptcy at judgment. Speed means decision before a shift in demand malies goods utterly worthless, or a drop in price necessitates quick dumping of the goods. As a result, sellers are able to retain disputed goods. ${ }^{121}$ Speed also makes possible the use of flexible remedies. Thus, an arbitration tribunal may require a buyer to accept substantially conforming goods without the fear that the goods are obsolete and worthless. Threat of quick action encourages replacement of defective goods and thus protects buyers' contracts with their own customers. ${ }^{122}$ Finally, fact-finding soon after the dispute arises undoubtedly minimizes the danger of perjured or mistaken evidence.

\section{Low Cost}

In all three tribunals fees charged on small claim cases are negligibleusually about one to two percent of the claim. ${ }^{123}$ Substantial savings result because of lack of appeals and costly records, and also because parties are permitted to present documents without witnesses and to dispense with counsel.

Although costs rise as claims get larger, arbitration is seldom an uneconomic expense in terms of size of recovery. ${ }^{124}$ Cost is low enough to permit

119. The case of NFT Docket No. 2,900 is a pointed illustration. Demand for arbitration was received on April 14. The tribunal sent 60 communications to the parties and 50 to the arbitrators in the course of the proceedings. Twelve third arbitrators were suggested. Some refused, some became unavailable, and some were unacceptable. Hearings were set for July 22, Sept. 29, Oct. 25, and Jan. 5, but each time they were postponed. Finally the parties withdrew the case after a settlement on June $6-3$ year and two months after the start of the proceedings.

120. The major delaying tactic is postponement. If one party does not want a postponement, the other party can gain a postponement only for cause, N.Y. Crv. PrAc. ACT $\$ 1454$.

121. Communication to the Yale LAw Journal from a broker, dated Feb. 15, 1952, on file in Yale Law Library, stating that arbitrators may deem prompt sale prejudicial to a buyer if the market is low. Merchants indicate that sellers do hold returned goods: seven merchants report that they settle disputes because of changed market conditions. INDUSTRY QUEstronNarRe. Furthermore, many awards call for delivery of goods with ut without allowance. Such delivery would be impossible unless goods were still unsold.

122. In interviews many merchants stated that this took place. A major reasen is that trade custom specifies that replacement rectifies non-conforming deliveries nu matter how severe the non-conformity may be. Replacement also destroys a buyer's right to reject future installments. WORTH STREET RULES 5 (rev. 1947).

123. See Rule 47 AAA (each party pays $11 / 2 \%$ of claims up to $\$ 10,000$ ); Rule 23 NFT (flat fee per amount involved-for example, $\$ 200$ for claims of more than $\$ 5,000$ and less than $\$ 10,000)$; Rule 13 GAC ( $\$ 25$ on claims up to $\$ 2,000)$.

124. See Rule 47 AAA; Rule 13 GAC; Rule 23 NFT. For claims above $\$ 25,000$ the NFT is cheapest. At $\$ 25,000$ NFT and GAC charge $\$ 230$ and $\$ 300$. For the same claim the A.AA charges each party $\$ 300$. 
firms readily to press all claims and defenses in disputes that cannot be settled amicably. ${ }^{125}$ Nevertheless, cost is high enough to induce some parties to accept slightly unsatisfactory settlements. ${ }^{126}$

\section{Experts}

Unquestionably the greatest asset of textile arbitration is its use of experts to evaluate the merits of each controversy. ${ }^{127}$ Textile experts with knowledge of market conditions and the variables of quality are sure to perceive a dispute induced primarily by declining price and colorable defect. ${ }^{128}$ Expert arbitrators are also essential for fair application of textile arbitration's flexible remedies, since the availability of certain remedies depends on the degree of non-conformity. Ability to assess the merits of claims and cross-claims and to apply the most stritable remedies requires intimate knowledge of the textile business.

So great is the need for experts that textile merchants often refuse to serve as arbitrators when their knowledge of trade custom applicable to the particular dispute is imperfect. ${ }^{129}$ And the NFT (rayon and silk) has banned non-textile men as arbitrators. ${ }^{130}$ The AAA (wool), on the other hand, allows selection of arbitrators who are not in textiles, but its panel lists include textile men. And woolen disputes over quality can be resolved by tests conducted by the Mutual Adjustment Bureau. ${ }^{131}$ Where the dispute is not or could not be resolved by the Mutual Adjustment Bureau, there are strong indications that textile experts are selected as arbitrators. Thus a majority of woolen merchants consider expert knowledge of major importance in select-

125. INDUSTRY QUESTIONNAIRE.

126. Complaints are aimed mainly at the costs in the AAA. IndUSTRY QUESTIONNAIR: and LAwYers' Questionnaire. Communication to Yale LAW Journal from a cutter, arbitrator for NFT and AAA, dated Dec. 28, 1951, on file in Yale Law Library: "Arbitration is much too costly. . . As a result, when one of the parties to a dispute is threatened with arbitration, even though he may be in the right, when he thinks of the costs involved he might make a settlement. This is decidedly unfair."

127. INDUSTRY QUESTTONNAIRE. Merchants believe that courts or jurics cannot approach the know-how arbitrators bring to bear on these intricate fact disputes. Sce Livesey, The Liverpool Cotton Association Limited System of Arbitration, 3 Akv. J. 158, 160,162 (1948), calling this arbitration's great advantage.

128. Industry QuestionNaire. See Stein-Tex Inc. v. Scappatillio, 193 Misc. 402, 87 N.Y.S.2d 317 (Sup. Ct. 1948), mod. \& aff'd 275 App. Div. 749, 88 N.Y.S.2d 270 (1st Dep't 1949). Arbitrators have a great advantage over courts because they are not restricted to evidence presented in the hearing. See Springs Cotton Mills v. Buster Boy Suit Co., Inc., 275 App. Div. 196, 200, 88 N.Y.S.2d 295, 298 (1st Dep't 1947), aff'd, 300 N.Y. 586,89 N.E.2d 877 (1949).

129. INDUSTRY QUESTIONNATRE.

130. Rule 4 NFT.

131. Industry Questionnaire See Berk Togs Inc. v. De Land Jr., 118 N.Y.L.J. 45, col. 3 (Sup. Ct. July 8, 1947) for a judicial discussion of the use of the Mutual Adjustment Bureau in quality disputes. 
ing arbitrators. ${ }^{132}$ Some bypass the panel system in order to assure the presence of experts. ${ }^{133}$

\section{Lessons Derived from Textile Arbitration}

Although textile arbitration is a success, it is not without defects. Speed, low cost, and utilization of experts are insufficient to guarantee equitable decisions in every case. In particular, the use of the tripartite system of choosing arbitrators, the employment of merchants as arbitrators, and the lack of records of prior decisions raise significant problems.

\section{Advocate Arbitration}

Rules of disqualification preclude the appointment of a customer or a friend as a party's arbitrator. ${ }^{134}$ But freedom of choice allowed in the tripartite system of selection permits parties effectively to circumvent the spirit of these rules by selecting men who will act as their champions. It is no secret that desire for an advocate sometimes motivates choice of arbitrators. ${ }^{135}$ Since each party selects one arbitrator, it is common to investigate an individual's availability before making a selection. ${ }^{130}$ In practice, many textile litigants take this opportunity to find an arbitrator who agrees with their position. ${ }^{137}$ Although most panel members would refuse to serve

132. In answer to the question "What do you consider in selecting an arbitrator," $60 \%$ of the respondent woolen merchants clearly indicated they wanted men well versed in the textile field. INDUSTRY QUESTIONNAIRE.

133. Ibid.

134. Rule 11 AAA; Rule 6 GAC; Rules 4, 14 NFT.

135. IndUSTRY QUESTIONNAIRE Of 51 cotton merchants who answered, 13 expect their arbitrator to serve as champion, and 15 out of $\mathbf{5 3}$ rayon and sillk merchants expeet their arbitrator to be their champion. Some textile men stated that this is why they arbitrate. Others disclaimed any desire for a champion, but nevertheless stated that their selection was based on finding a man who "sees their side of the case." One converter reported that he wanted an advocate and so did everybody clse, although they would not admit it.

136. Since unavailability is a common ground for refusal to serve as an arbitrator, INDUSTRY QUESTIONNAIRE, somebody must investigate availability before selection. In practice, parties themselves often do it. Thus, over 50 per cent of the responding arbitrators on tripartite boards report that parties had contacted them. INDUSTRY QUESTrovisame.

137. The only opportunity to find an advocate is during the "investigation" into availability. The mechanism for finding advocates is as follows: The party calls a merchant, discloses his case, and asks the merchant what he thinks. If agreement is indieated, the party then asks the merchant to serve as an arbitrator. Interviews with textile merchants indicate that if there is disagreement or if the merchant agrees but refuses to serve, another telephone call is made. Advocacy is most likely where men not on a tribunal's panel list are asked to arbitrate. Industry Questionsiare. Non-listed merchants may well not know of the rule prohibiting advocacy. Apparently a major reason why parties seek an advocate is their fear that the other party has or will make a selection on the same basis. Ibid. 
rather than honor such a request, ${ }^{138}$ selection is not limited to the panel list of the GAC or the NFT. ${ }^{130}$ And non-panel members who are asked to serve as arbitrators may not know that advocacy is contrary to the rules of the tribunal. As a result, a party can get an advocate into the fact-finding and decision-making process. When only one side is represented by an advocate, the merits of the case may be distorted because that side receives undue consideration. If the advocate is a textile expert, his influence may be augmented, especially if he is able to put more pressure on the impartial arbitrator than the other party's nominee-and there is no rule preventing one arbitrator from being a customer or friend of another. ${ }^{140}$ Where both sides select advocates as arbitrators, fact-finding and decision-making will in effect be left to one man. ${ }^{141}$ Since few individuals know all phases of trade custom or are objective about it, arbitration by advocates increases the chances of injustice. ${ }^{142}$

There are three possible reforms which would lessen the possible consequences of advocate arbitration. The first is to extend rules of disqualification to cover the relationship between the two parties' arbitrators and the impartial chairman. This would reduce the potential influence of an advocate over the third arbitrator. But these rules would not strike at parties' power to choose advocates. A second reform would be to forbid selection of men not included on a tribunal's panel list. Finding an advocate would be more difficult because panel members disqualify themselves in the event of pre-hearing disclosure. ${ }^{149}$ A third solution is to adopt a system of bipartisan choice of all three arbitrators. Because the arbitration tribunal alone knows both parties' list of preferences and therefore first informs the arbitrators of their selection, choice of an advocate is virtually impossible. Since both parties approve of each arbitrator, neither represents any one party.

138. Industry QUESTIONNAIRE. Early disclosure is ground for disqualification, Rulc 14 NFT, and partiality is outlawed by N.Y. Crv. PrAc. ACr $\$ 1462-3$.

139. Rule 4 NFT; Rule 6 GAC. In both tribunals, however, one arbitrator must come from a panel list. The third arbitrator is almost invariably a panel member on the arbjtration board. Interview with H. A. Sherman and Irene Blunt.

140. Merchants report that it is often difficult for textile men serving as arbitrators to divorce themselves from their own business interests. Thus, if one party is a powerful company and appoints its arbitrator from another equally potent firm, the pressurc on a third arbitrator may be tremendous. INDUSTRY QUESTIONNAIRE.

141. One lawyer reports: "My personal experience is that arbitrations where the parties each select an arbitrator and these two select a third is unsatisfactory because the arbitrators chosen by the parties generally become partisans and the stbmission is thus left to one neutral arbitrator." LAwYERs' QuestionnarRe. This report is typical. Ibid.

142. Textile men prefer three man to one man arbitration. INDUSTRY QuestionNAIm:. Of 112 merchants in cotton, rayon, silk, and wool, 108 desire three man arbitration. The significant facts, however, are the reasons for the preference. Most merchants gave as reasons one or more of the following: three men guaranteed a fuller discussion of evidence, a less arbitrary approach to the issues, fairer hearings, and more expert knowledgc brought to bear on the case.

143. N.Y. Crv. Prac. ACt $\$ 1456$. See also Rulc 27 GAC. 


\section{Compromise}

Although in few cases is one party completely right, ${ }^{14 t}$ awards by textile boards are almost always unanimous. Thus, only $1 \%$ of the cotton awards and about $10 \%$ of the rayon and silk awards are split decisions. ${ }^{145}$ This unanimity indicates that many decisions are adjustments of claims. Most adjustments are considered valid and equitable. ${ }^{1: 6}$ But many merchants insist that there are too many compromises. Unnecessary compromises may result either because merchant arbitrators are reluctant to be harsh to a party or because of the uncertainty inherent in technical textile disputes. Compromise beyond the point required by the merits of a case may produce unfairness which detracts from the utility of arbitration.

\section{Rigid Interpretations of Trade Custom}

Decisions made by experts from the textile industry may reflect their personal experience of trade custom. Where trade custom is not codified, each trade within the industry often has its own interpretations. ${ }^{147}$ For example, trade custom differs basically as between converters and cutters. ${ }^{245}$ An arbitrator from either of the trades involved in a dispute might bring his own trade interpretation into the arbitration. ${ }^{140}$ Such trade bias is

144. IndUSTRY QUestionnaire.

145. These are rough estimates made by administrators of the two tribunals. Interviews with Irene Blunt and $\mathrm{H}$. A. Sherman.

146. Many merchants report that compromise is usually realistic and equitable. Few cases are cut and dried, and the availability of flexible remedies permits decisions to be based on the balance of wrongs or rights on each side. INDUSTRY Questow:anme

147. In cotton, WoRTH STREET RULEs have resolved much of the earlier disagreement on trade custom. Compare Worta Street Rules (rev. 1947) fussim with correspondence between two of the draftsmen of the rules, letters dated June 12, and June 14, 1934, copies on file in Yale Law Library. Before the rules, major disagreement was over the inclusion of second quality cloth in each shipment, grace periods after delivery, and the meaning of trade terms. In rayon, where there is virtually no agreement, conflict on the meaning of trade custom is rife. For example, in the Texmin Distaibutons Iristitute, Stasidands FOR THE EXANINATION of Finished Goods 2 (1950 ed.), the confict between weaver or converter and cutter is evidenced by the following: "The customer (cutter) is not interested in the cause of a defect. He is interested in how much loss in cutting will be necessitated." Id. at 2 . Yet the definitions of imperfections reflect the manufacturer's interest that "normal irregularities natural to the fibers used" exist and that "a reasunable number of manufacturing defects must be expected." The standards leave "normal irregularities" undefined. Ibid. There is basic disagreement on what non-conformity is. IsDUSTRY QUESTIONNAIRE

148. INDUSTRY QUESTIONNAIRE. Of ten cutters, three feel that there is a body of trade custom, but seven report the field is fluid. This is corroborated by many converters. See for example, communication to the Y.LLE LAW JounNal from a converter, dated Jan. 15, 1952, on file in Yale Law Library (blaming any failing in NFT on lack of mutually acceptable trade practice).

149. Many merchants stated expressly that one man might incorporate his trade bias in the fact-finding process. Innustry QUestionnarre. 
capable of producing injustice if the third arbitrator fails to take a neutral position between the competing interpretations. Where the third arbitrator sides wholly with one view of trade practice, he is likely to perceive no equity on the other side. ${ }^{150}$ The structure of the industry is such that in some cases it will be impossible to find a man who occupies a middle position and yet knows enough about the issues in a dispute to qualify as an expert. An example is a dispute between cutter and converter, for there is no trade between them. The third arbitrator must be a man from one of the two trades or from a trade allied with one or the other. ${ }^{161}$ Whichever trade he comes from, he will be familiar with that trade's interpretation of custom, and will therefore tend to join with that tride's arbitrator in rendering a decision. ${ }^{152}$

\section{Predictability and Trade Custom}

Textile awards are seldom supported by written opinions. ${ }^{168}$ And the award itself will indicate little about the rationale behind the decision, especially if facts and claims are complicated. This safeguards decisions against court attacks based on the poor reasoning of an opinion written by merchants inexperienced in legalistic writing. ${ }^{154}$ But knowledge of the way arbitrators

150. INDUSTRY QUESTIONNAIRE. See, for example, answer of large silk mantufacturer. "The mills usually will not accept a third party unless he is a millman or a factor. The board is two to one against a manufacturer and unless the manufacturer is $100 \%$ right, a compromise award or a mill victory is the outcome. They do not want to admit the mill errors are controllable and always try and stick together and pass along their mistakes."

151. The transaction between converter and cutter is the middle point between sellers (weaver and converter) and buyers (cutter and retailer). All trades behind the converter have his view of disputes-one which would disregard imperfections and force the buyer to accept the goods; while all trades from cutter to consumer have the same view-favoring rejection for imperfections. The reason that an arbitrator must be from one trade or the other is that there is no trade between the two which has the orientation of both and from which an arbitrator can be selected. One example of a neutral trade between two "conflicting" trades is that of the broker who stands between mills and converters. His dealings include placing orders of cloth from mills for converters and placement of sales for mills to converters. Communication to the YaLE LAW Journal from a broker, dated Jamuary 10, 1952, in Yale Law Library.

152. Some converters state that the possibility of trade bias is so great in the abscnce of agreement on trade custom that they will not go to arbitration. Settlement is the means of enforcement. INDUSTRY QUESTYONNAIRE.

153. Blunt, An Arbitration Workshop 12 (1939). N.Y. Civ. Prac. Act $\$ 1460$ is silent on writing opinions; therefore, they are not necessary. Tribunals' rules arc also silent. See Rules 40-6 AAA, Rule 19 NFT. Cf. Rule 5 GAC (discretionary). Courts will not, of course, upset an award simply because there is no opinion, for they cannot review the merits in any event. See Arcola Fabrics Corp. v. Brenda Modes, Inc., 273 App. Div. 891, 78 N.Y.S.2d 46 (1st Dep't 1948).

154. Courts may vacate awards which fail to carry out the arbitrators' intent. Sce Sturges, Commerctal Arbitrations and Awards $792-3$ (1930). 
construe controversial aspects of trade custom, or, for example, unfair clauses in contracts, would be of great significance to members of the industry. 155

Arguments against opinions and precedent are compelling. That three merchants selected by two disputing merchants should legislate for the entire industry on debatable aspects of marketing procedure seems singularly unwise. Written opinions are likely to incorporate trade bias and preserve it. Nor is there any guarantee that the many different arbitrators will be able to understand an opinion or follow it. If written opinions served as more than a guide to show what three arbitrators felt about an issue in a specified case, they would complicate arbitration and frustrate flexibility. And there is little doubt that requiring written opinions would restrict the number of available arbitrators. For not only is opinion-writing time consuming but textile men might be reluctant to expose their reasoning to the criticism of customers and competitors. Finally, written opinions would drive from arbitration parties who would not risk the adverse publicity which any dispute generates. ${ }^{160}$

A better way to get predictability would be by codifying trade customs and marketing terms in a form to which all trades would agree. Codification restricts the areas in which an arbitrator can unconsciously implement trade bias. Lack of mutually acceptable codes of trade custom in rayon has in large part been responsible for any dislike of rayon arbitration. ${ }^{107}$ Agreement on codified trade custom in cotton, on the other hand, has been a major factor in the success of its arbitration. ${ }^{158}$

\section{Arbitration and Settlements}

Arbitration has had a marked impact on the type of dispute which is formally enforced. Speed, low cost, and use of experts have reduced the number of disputes in textiles, for all three attributes make arbitration freely available and thus restrain blatant breach. ${ }^{159}$ But the most significant effect of arbitration is that it has encouraged private adjustment in approximately 99 per cent of textile disputes. ${ }^{160}$ Where each side realizes the validity of the other's

155. One cotton merchant decried lack of a growing body of case law from arbitrations. INDUSTRY QUESTIONNAIRE.

156. Despite the absence of written opinions many firms settle rather than face publicity which may damage their product's good name. Furthermore, some sellers, aware that their buyers resent unfair contracts, are wary of enforcing them. Ilbid.

157. Interviews with rayon merchants indicated that lack of codification was a major shortcoming. Communication to Yale Law Jourisal from a weaver, dated January 11, 1952, on file in Yale Law Library.

158. INDUSTRY QUESTIONNAIRE.

159. InDustry QUestionNaIRE. Textile men invoke arbitration as a matter of principle in the face of a clear breach. Ixpustry Questioxxare. See Halstead, Arbilration Group Wins Recognition of Textilc Trade, 1 ARB. J. 290, 291 (1946).

160. Out of 86 merchants in silk, rayon, and cotton, 83 usually settle their disputes privately. The three who report they do not settle have had practically no disputes. \& gave the approximate percentages of their disputes which had gune tu arbitratiun: 63 re- 
claim, the probability that an arbitration award will reflect the true equities induces parties to settle rather than waste their time to no advantage. ${ }^{101}$ of those cases that go to arbitration, one-half are settled privately before hearing. ${ }^{162}$

But the easy availability of arbitration and the supposed tendency of arbitrators to compromise has also created an atmosphere which brings weak cases to arbitration. ${ }^{163}$ A party with a weak case will get little in a private settlement; instead he may invoke arbitration in the hope of a more favorable award. ${ }^{164}$ Faced with this possibility the other party may agree to an unjust settlement.

\section{Use of Counsel}

Over half the parties to textile disputes normally employ counsel during arbitration preliminaries. ${ }^{165}$ Counsel are also permitted to attend wool and

port less than $1 \%$; three report $2 \%$; two report $5 \%$; three report $10 \%$; and five report from $50 \%$ up. These figures exclude brokers, factors, and finishers, who do not buy or sell goods and hence do not arbitrate.

The major reasons for settlement are: (1) small size of claims; (2) customer rela tions; and (3) balanced equities in the dispute. INDUSTRY QuESTIONNAIRE.

161. Of 74 merchants who usually settle privately, 43 report divided merits in the dispute was a reason for settlement. 27 considered it crucial. 22 reported settlement occurred where one party was wrong. 13 considered this a crucial reason for settlement. INDUSTRY QUESTTONNAIRE.

162. NFT statistics for 1950 , for example, show that 133 awards were made, and 133 disputes were withdrawn. Withdrawals and settlements during arbitration are not limited to small claims. Of eight NFT disputes involving claims over $\$ 45,000$ in 1950 , five were withdrawn from arbitration. See NFT Docket Nos. 3555, 3593, 3595, 3621, and 3643. Onc reason for the high percentage of settlements is use of arbitration as a threat. Ten of thirty rayon and silk merchants stated that they invoke arbitration as a threat. INDUSTRY QUESTIONNAIRE.

Settlements during arbitration can be made into awards if parties desirc. Rule $43 A A A$. Where the settlement is not made into an award and the agreement is subsequently broken, arbitration retains jurisdiction. In re Peerless Clothing Co., Inc. v. Forge Mills, Inc., 118 N.Y.L.J. 133, col. 2 (Sup. Ct. July 23, 1947).

163. Of 70 rayon, silk, and cotton merchants, 10 indicate they would not be interested in the merits of their case if other considerations are present-size of damage and possibility of using arbitration as a threat to gain a good settlement. INDUSTRY QUESTIONNA1kE.

164. Communication to the Yale Law Journal from a cutter, dated Dec. 28, 1951, in Yale Law Library: "I have seen where arbitrators very often feel that they dislike to hurt either of the parties and bring in a compromise verdict. This very often will tend to influence a party who is in the wrong to bring an arbitration proceeding, and at the same time may cause a person who is in the right to settle when threatened with an arbitration proceeding."

165. IndUSTRy QUestionnaire. In AAA the figure may be higher. See Gotshal, Thic Lawyers Place in Arbitration, 1 ARB. J. 369 (1946) putting the figure close to 80\%. In GAC, out of 42 merchants reporting, 25 always employ counsel in preliminaries and three sometimes use lawyers. INDUSTRY QUESTIONNAIRE. In NFT out of 39 merchants reporting, 22 always employ counsel in preliminaries. Ibid. NFT figures on 1947 and 1948 show 
cotton hearings ${ }^{106}$ and, because of each party's fear of being at a disadvantage, counsel are present in most proceedings. ${ }^{167}$ In the rayon and silk tribunal, however, since either an arbitrator or a party may exclude lawyers, ${ }^{10 s}$ they are present in only 5 per cent of the hearings. 160

Despite lawyers' belief in their usefulness, ${ }^{170}$ most merchants feel that the presence of counsel in textile hearings is detrimental. The expense alone is wasteful. ${ }^{171}$ In addition, lawyers are of little assistance in quality disputes. ${ }^{172}$ Lawyers interfere with expert arbitrators who are well equipped to examine and cross-examine with finesse and speed. ${ }^{173}$ Lawyers automatically destroy informality $;^{174}$ parties are put on their guard. Most arbitrators in all three tribunals consider counsel undesirable. ${ }^{175}$ In fact, many would refuse to

that in 340 out of 725 cases filed counsel handled preliminaries. NFT MFesozasinuss Opposing Assenrbly Binl INT. No. 11274 (1949). But NFT admits these figures may be incomplete. Ibid.

166. Rule 21 AAA; Rule 11 GAC. But Rule 11 GAC allows arbitrators to expel counsel "if in their opinion the bounds of proper deportment are exceeded."

167. Although only $25 \%$ of the textile merchants queried desire to be represented by counsel at a hearing, counsel are present in about gor; of the hearings before the AAA and in well over $50 \%$ of those before the GAC. One possible explanation for this is merchants do use counsel in preliminaries, actual notice of intent to bring counsel may never $A A A$ provides for notice to an opponent that a party intends to be represented by counsel. But use of a lawyer in preliminaries constitutes notice. Since a majority of testile merchants do use counsel in preliminaries, actual notice of intent to bring counsel may never be made. Hence many merchants, faced with this implied notice, may bring counsel to AAA hearings just in case their opponent does so, for there is no way of telling beforehand if counsel will be present.

168. Rule 17 NFT.

169. In 1947 and 1948 , out of 725 cases (1450 parties) 86 requests for counsel were received and 29 granted. NFT Mearorandus Opposing Asseasbly Bill Ixt. No. 1127 2-3 (1949).

Exclusion of lawyers had been tested in courts and upheld. In Knicl:erbocker Testile Corp. v. Ginsberg, 121 N.Y.L.J. 468, col. 1, Feb. 5, 1948, the court held that exclusion under NFT rules was neither void as against public policy nor a violation of due process.

170. LAWYERS' QUESTIONAAIRE.

171. INDUSTRY QUESTIONNAIRE.

172. Ibid. Some firms which use counsel in hearings would not use them for quality disputes. Two lawyers report that they consider themselves quite unnecessary, if not detrimental, in a quality dispute. But other lawyers do not agree. LAwYens' QuEsTrominare.

173. INDUSTRY QUESTIONNAIRE.

174. Ibid. As one merchant expressed it, "A lawyer is a stranger." Others feel that if counsel are present they might as well go to court. And there is little doubt that informality is lost, especially in arguments over admissibility of evidence. See also NFT Meziorandial Opfosing Assenibly Binl Int. No. 10586 (1951).

175. INDUSTRY QuestionNaIRE. Wool (AAA): Of six arbitrators serving exclusively in the AAA, two consider counsel helpful; four consider them detrimental. Of sis: who serve with AAA as well as on other tribunals, one feels counsel are bencficial; five consider them detrimental. Cotton (GAC): Of 52 arbitrators, twelse consider counsel belpful, 37 consider them detrimental, and three say that it depends entirely un cuunsel. Rayon, silk (NFT) : Of 50 arbitrators, five feel counsel are beneficial, 42 consider them detrimental, and three report that it depends on the particular lawyers. 
serve when a lawyer is present. ${ }^{176}$ Counsel cannot argue precedent. Furthermore, arbitrators are not held to the law, and legal issues are rarely significant. ${ }^{177}$ Counsel cannot correct the weaknesses of arbitration. To allow counsel, therefore, causes additional expense, possible delay, possible irritation, and few benefits in most proceedings. Hence relatively few merchants desirc to bring counsel to hearings-unless their opponent does so. ${ }^{178}$ Practically no merchant asserts that a lawyer is indispensable. True, counsel may present a case better than a merchant could. And lawyers experienced in textile arbitration may help in other aspects of cases. ${ }^{170}$ But since valuable lawyers are hard to separate from ones whose presence would be detrimental, the best solution is to bar representation by counsel in textile proceedings generally except where it is shown that lawyers are specially needed.

\section{SUMMARY}

Arbitration is a flexible system of self-government adaptable to the individual requirements of any industry. Disputes can be resolved with as much speed as necessary. Arbitration can be kept inexpensive since costs may be assessed according to the size of claims, and the member trade associations can also subsidize arbitration in order to alleviate the burden on litigants. The major problems of textile arbitration derive from its special need for

176. InDUSTRY QUESTIONNATRE. AAA:Of twelve woolen merchants who serve as arbitrators on AAA, six of whom also serve on other tribunals, five would decline and one would prefer not to serve. GAC: Of 62 cotton arbitrators, ten would decline and four would prefer not to serve. NFT: Of 58 rayon and silk arbitrators, nineteen would declinc and five more would prefer not to serve.

177. An award will not be upset merely because of error of law. See, c.11., Gilt Edge Textile Corp. v. Princeton Rayon Corp., 120 N.Y.L.J. 1575, col. 3 (Sup. Ct. Dec. 17, 1948) (retention of merchandise waives the right to claim that delivery was improper although the goods were not of the type contracted for; NFT award confirmed since arbitrators need not comply with principles of law governing courts). See Commercial Arbitration Developed in Trade Courts, 7 J. Ax. Jun. Soc'y 7-9 (1923) (questions of law in Illinois and England may be submitted to a special commercial court).

Arbitrators are not even restricted to evidence introduced at the hearing unless the submission so stipulates. See Springs Cotton Mills v. Buster Boy Stit Co., Inc., 275 App. Div. 196, 200, 88 N.Y.S.2d 295, 298 (1st Dep't 1949), aff'd, 300 N.Y. 586, 89 N.E. 2d 877 (1949).

178. See NFT Mexrorandum Opposing Assembly Bill 1Nt. No. 10582 (1951). Of 46 rayon and silk merchants only four desire counsel at hearings. INDUSTRY QUESTIONNAIRE. GAC: Of 44 cotton merchants eleven desire counsel to attend hearings. AAA: Of five woolen merchants, four desire counsel at hearings; some said that counsel was given better treatment than parties.

179. This is corroborated by textile merchants. InduSTRY QUESTIONNAIRE. Counsel are of benefit in (1) clarifying facts not connected with quality (2) clarifying the law (3) discrediting opponent's evidence (4) ensuring that all procedural rights are granted (5) and detecting signs of partiality. But there are obviously few lawyers who are contsidered experienced. Some lawyers who are experienced in textile arbitration recognized the prevalence of inept counsel. LAWYers' QUESTIONNAIRE. 
experts. The search for busy merchants willing to sacrifice working time to hear disputes may cause delay. Use of industry members evidently lessens chances of maintaining privacy. And use of experts in a centralized and troubled industry sometimes results in advocacy, trade bias, and unjust compromise. Advocacy, however, can be minimized by instituting the panel system of selection. Trade bias can be curtailed by promulgation of codes acceptable to all branches of the industry. And with those two reforms the number of unjust compromises would be reduced. In other industries, where experts are not so necessary, these problems might not even arise. But even with its present defects, textile arbitration offers businessmen a simple and highly successful alternative to litigation. 